\title{
De gamle Rømøhuse
}

\section{Af Aksel Skov}

Blandt de gamle Rømøhuse fra øens storhedstid i 1700-årene er Nationalmuseets kommandørgård i Toftum og Rømø-gården på Frilandsmuseet i Lyngby almindeligt kendte. Kommandørgården er ikke en typisk Rømøgård. Der er ingen andre gårde på øen, der ligner den, og Rømøgården i Lyngby var nok tidligere typisk for bondegårdene; men disse er nu ombygget, så der kun er lidt eller intet tilbage af deres oprindelige form og udseende.

Derimod er mange huse, kådnerhusene, hvor landbruget ikke var hovedsagen for beboerne, nogenlunde godt bevaret, især i det ydre, og de er også en omtale værd. Mange af disse huse er desværre forsvundet $i$ forrige og begyndelsen af dette århundrede, da øens indbyggerantal gik stærkt tilbage. Endnu ses hustomterne som svage hævninger i terrænet, hvor græsset er grønnere end normalt p̊̊ grund af jordens kalktilskud fra murmørtelen. Aldre Rømøser kan fortælle, hvordan nedbrydningen af et hus foregik i nedgangstiden. Det stod tomt og forfaldt, fordi der ikke var købere til det efter de gamle beboeres død. En nabo trængte måske til et nyt vindue og fandt, at der var et i det tomme hus, han kunne bruge, og så hentede han det. På den måde forsvandt den ene bygningsdel efter den anden, indtil kun tomten lå tilbage. Når man nu gennemgår enkelthederne i gamle Rømøhuse, finder man vinduer, døre og paneler, der er indbyrdes forskellige og fra forskellige tider. En del af dem er formodentlig hentet $i$ huse under nedrivning, men andre kan nok stamme fra et ældre hus på stedet.

De gamle Rømøhuse kan med et moderne ord kaldes typehuse af det åbne system, hvilket vil sige, at de er opført af (nogenlunde) standardiserede elementer, der kan anvendes til forskellige husstørrelser og planløsninger. De er resultatet af en fast tradition med hensyn til orienteringen, indretningen, konstruktionerne, målene og materialerne.

\section{Byggeprogrammet}

Husene var altid orienteret øst-vest. Indgangen var i sydsiden og dannede skel mellem boligen og stalden. Dette er ikke specielt for Rømø; det ses ved mange huse i Sønderjyllands vestegne. Det almindeligste var, at stalden og loen var $\mathrm{i}$ husets vestende, hvor de optog 1, 2 


\begin{tabular}{|c|c|c|c|c|c|c|c|c|c|c|c|c|c|c|c|c|c|c|c|c|}
\hline $\begin{array}{l}5 \\
5 \\
5 \\
5 \\
5 \\
3 \\
3 \\
3 \\
3\end{array}$ & है & $\begin{array}{l}\text { ई } \\
\text { है } \\
\text { है }\end{array}$ & है & ఫे & ปै & 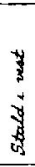 & 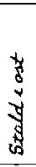 & 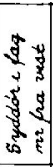 & 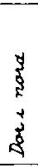 & $\begin{array}{l}\text { है } \\
3 \\
5 \\
5 \\
5 \\
5 \\
5 \\
5\end{array}$ & 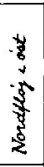 & $\begin{array}{l}\text { है } \\
5 \\
5 \\
\frac{5}{5} \\
\text { है }\end{array}$ & 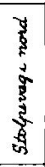 & 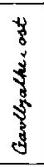 & है & 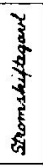 & 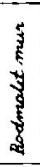 & $\begin{array}{l}5 \\
\text { है } \\
\text { है } \\
\text { है }\end{array}$ & $\begin{array}{l}3 \\
\text { है } \\
\text { जै } \\
\text { है } \\
\text { जै }\end{array}$ & है \\
\hline 5 & 222 & 9 & 0 & & 4 & 8 & & 5 & & & & & & & & & 0 & & & \\
\hline 19 & 36 & 8 & $\theta$ & & 2 & & 0 & 6 & & 0 & & & & & & & (2) & & & \\
\hline 20 & 188 & 9 & 8 & & 3 & 2 & & 4 & & & & & & & & $\theta$ & 0 & & & \\
\hline 21 & $42 \mathrm{~J}$ & 9 & $\theta$ & & 3 & $\theta$ & & 4 & & $\otimes$ & & & & & & & 0 & & & \\
\hline 22 & $23 \mathrm{~J}$ & 5 & & $\theta$ & 2 & & & 4 & & & & & & & & & -1 & & & \\
\hline 26 & $77 \mathrm{~J}$ & 8 & & $\theta$ & 3 & $\theta$ & & 5 & & & & & & & & & 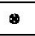 & & & \\
\hline 27 & $33 \mathrm{~J}$ & 8 & 8 & & 2 & & $\theta$ & 6 & & & & & & & & & 0 & & & \\
\hline 28 & $32 \mathrm{~J}$ & 4 & $\otimes$ & & 1 & $\theta$ & & 2 & $\theta$ & & & & & & & & - & & & \\
\hline 29 & $38 \mathrm{~J}$ & 4 & 8 & & $l$ & & $\theta$ & 3 & & & & & & 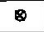 & & & 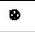 & & & \\
\hline 35 & $\begin{array}{l}622 \\
k 60\end{array}$ & 9 & $\otimes$ & & 2 & $\theta$ & & 3 & & & & & & 0 & & & 0 & & & \\
\hline 37 & $6 \%$ & 8 & $\otimes$ & & & & & $I$ & & & & & & & & & 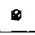 & & & \\
\hline 38 & $56 \pi$ & 4 & & $\theta$ & 1 & $\theta$ & & & & & & & & & & & & & 0 & \\
\hline 40 & $39 K_{0}$ & 8 & $\otimes$ & & 2 & 8 & & & 0 & & & & & & & & $\Delta$ & & & 8 \\
\hline 41 & $40 \mathrm{~K}$ & 8 & & $\theta$ & & & & 4 & & 0 & & & & & & & & & & $\theta$ \\
\hline 43 & $58 \mathrm{~K}$ & $n$ & & $\theta$ & 3 & 0 & & $M$ & $\theta$ & & & & & & 8 & & & & & $\otimes$ \\
\hline 45 & $46 \%$ & 8 & $\theta$ & . & 2 & $\theta$ & & 3 & & & & & & & & & 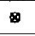 & & & $\theta$ \\
\hline 47 & $47 \hbar^{\circ}$ & 9 & & $\otimes$ & 2 & & & 5 & & $\theta$ & & & & & & & 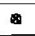 & & & \\
\hline 48 & $45 \%$ & 8 & $\theta$ & & 2 & $\infty$ & & 5 & & & & & & & & & t & & & \\
\hline 40 & $25 \%$ & 6 & 8 & & $l$ & $\theta$ & & 2 & & & & & & & & & & & & 8 \\
\hline 50 & $\begin{array}{c}567 \\
60\end{array}$ & 7 & & $\theta$ & 2 & $\theta$ & & 5 & & & & & & & & & & & & $\theta$ \\
\hline 51 & $43 \%$ & 10 & 8 & & 3 & 8 & & 4 & & & & & $\theta$ & & 8 & & $\star$ & & & \\
\hline 52 & $42 \kappa_{0}^{\circ}$ & 10 & $\phi$ & & 3 & & $\infty$ & 4 & & & $\theta$ & & & & & & & $\theta$ & & \\
\hline 53 & $26 \mathrm{~N}^{\circ}$ & 9 & $\theta$ & & 3 & & 8 & 4 & & & $\theta$ & & & & & & 0 & & & \\
\hline 54 & SI/10 & 12 & 8 & & 4 & $\theta$ & & 8 & & & & & & & 8 & & & & & $\theta$ \\
\hline 55 & $3 i \kappa_{0}$ & 9 & & $\theta$ & 3 & & 8 & 4 & $\otimes$ & & & & & & & & $\sigma$ & & & \\
\hline 56 & $32 \%$ & 9 & & 8 & 3 & 0 & & 4 & & 8 & & & & & 0 & & $\otimes$ & & & \\
\hline 57 & $28 \%$ & 8 & $\otimes$ & & 2 & 2 & & 5 & & & 0 & & & & & & & $\otimes$ & & \\
\hline 58 & $29 \mathrm{~K}$ & 8 & 8 & & 2 & 2 & & 5 & & & 0 & & & & $\theta$ & & & & & $\theta$ \\
\hline 59 & $19 \%$ & 6 & $\theta$ & & 2 & 2 & & & & & & & & & & & & $\otimes$ & & \\
\hline 60 & $22 k 0$ & 9 & $\theta$ & & 2 & $\theta$ & & 5 & 0 & & & & & & & & & & & $\theta$ \\
\hline 61 & $84 \pi$ & 4 & $\theta$ & & 1 & 8 & & $2 "$ & $\theta$ & & & & & $\theta$ & & & 0 & & & \\
\hline 64 & $\begin{array}{c}782 \\
K c_{0}^{2}\end{array}$ & 10 & $\infty$ & & 2 & & 8 & 7 & & & 6 & & & & & & $\otimes$ & & & \\
\hline $65^{\circ}$ & $18 K_{0}$ & 9 & $\theta$ & & 2 & & 8 & 6 & & 8 & & & & & & & $\infty$ & & & \\
\hline 66 & 536 & 7 & 8 & & 2 & $\otimes$ & & 3 & & & & & 0 & & & & 0 & & & \\
\hline 68 & $\begin{array}{l}356 \\
56\end{array}$ & 7 & 8 & & 2 & & & 3 & 8 & & & & & & & & 2 & & & 8 \\
\hline 69 & $12 \%$ & 9 & & $\theta$ & 3 & & & $M$ & $\theta$ & & & & & & & & & & & $\otimes$ \\
\hline 72 & 4950 & 8 & & $\otimes$ & 2 & & & $M$ & 8 & & & & & & & & & & & 8 \\
\hline 75 & $34 \sqrt{60}$ & 13 & 8 & & $?$ & 8 & & 6 & & $\theta$ & & & & & & & $\theta$ & & & \\
\hline $7 y$ & $13 \mathrm{~K}_{0}$ & 10 & $\otimes$ & & 3 & $\theta$ & & 6 & & & & & $\theta$ & & & & 8 & & & \\
\hline 80 & $60 K_{0}$ & 7 & $\theta$ & & 2 & $\theta$ & & 3 & & & & & $\theta$ & & & & $\theta$ & & & \\
\hline 83 & $48 \mathrm{Kk}$ & 7 & 8 & & 2 & & $\otimes$ & 5 & & & $\theta$ & & & & & & $\theta$ & & & \\
\hline 83 & $74 \mathrm{~K}$ & 7 & & $\otimes$ & $o$ & . & & 5 & & & & & & & & & & & & $\theta$ \\
\hline 86 & $\begin{array}{ll}115 \\
\pi \varepsilon\end{array}$ & 9 & 8 & & 2 & 8 & & $M$ & & & & & & & & & $\theta$ & & & \\
\hline
\end{tabular}

ROMФSKE HUSE Sammenlagnenger it hevere Ko Kongsmark. The Kirkeby

Skema over de typiske bygningselementers fordeling $i$ de gamle Romøhuse. $-J=J u v r e, K o$ $=$ Kongsmark, $K i=$ Kirkeby. Tallene $i$ forste kolonne henviser til nummereringen af husene $i$ den registrering, der 1971 blev udgivet af Foreningen for bygnings- og landskab- 


\begin{tabular}{|c|c|c|c|c|c|c|c|c|c|c|c|c|c|c|c|c|c|c|c|c|}
\hline 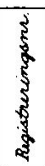 & $\frac{2}{2}$ & $\begin{array}{l}\text { इे } \\
\text { है } \\
\text { है }\end{array}$ & s. & ș & 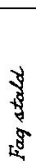 & \begin{tabular}{l}
$W$ \\
3 \\
2 \\
\multirow{3}{*}{} \\
\multirow{3}{*}{}
\end{tabular} & 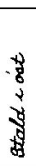 & 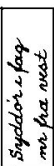 & $\begin{array}{r}\$ \\
5 \\
-\frac{1}{5}\end{array}$ & 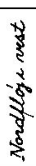 & 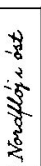 & 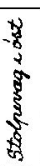 & 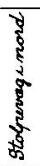 & 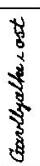 & $\frac{\mho}{3}$ & है & $\begin{array}{l}\text { ई } \\
\text { है } \\
\text { ज़ } \\
\text { है } \\
\text { है }\end{array}$ & $\begin{array}{l}\text { ई } \\
\text { है } \\
\text { है } \\
\text { है }\end{array}$ & $\begin{array}{l}\text { ई } \\
\text { है } \\
\text { है } \\
\text { है } \\
\text { जै }\end{array}$ & है \\
\hline 88 & $\begin{array}{c}675^{\circ} \\
\mathrm{ka}\end{array}$ & 11 & $\otimes$ & & 2 & $\theta$ & & & $\otimes$ & & & & 6 & 8 & $\theta$ & & $\theta$ & & & \\
\hline 89 & $\begin{array}{c}212 \\
K i\end{array}$ & 7 & $\theta$ & & 2 & $\otimes$ & & 3 & $\otimes$ & & & $\theta$ & & 8 & & & & $\otimes$ & & \\
\hline 90 & $15 \% \mathrm{i}$ & 10 & & $\otimes$ & & & & $M$ & & $\theta$ & & & & & $\theta$ & & & & & $\theta$ \\
\hline 92 & $84 k \varepsilon$ & 5 & $\otimes$ & & 2 & $\theta$ & & & & & & & & & & & & & 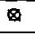 & \\
\hline 93 & 63K & 6 & $\otimes$ & & & & & 6 & 8 & & & & & & & & $\theta$ & & & \\
\hline 94 & $\frac{449}{12}$ & 7 & $\otimes$ & & 2 & & $\otimes$ & 3 & & & & & & & & & & $\theta$ & & \\
\hline 95 & $12 k i$ & 8 & $\otimes$ & & 2 & & $\varnothing$ & 6 & & & $\otimes$ & & & & & & & & & $\$$ \\
\hline 96 & $\begin{array}{l}100 \\
R\end{array}$ & 6 & 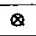 & & 2 & $\theta$ & & 3 & $\otimes$ & & & & $\theta$ & 8 & & & & 8 & & \\
\hline 97 & ${ }^{42} K^{6}$ & 7 & $\otimes$ & & 2 & $\otimes$ & & 2 & & & & & $\theta$ & & & & & $\otimes$ & & \\
\hline 98 & $\begin{array}{c}104 \\
\mathrm{Ka}^{4}\end{array}$ & 6 & $\theta$ & & 3 & $\theta$ & & & & $\otimes$ & & & 8 & & & & & $\theta$ & & \\
\hline 100 & ${ }^{595}$ & 7 & $\otimes$ & & $?$ & ? & $?$ & 6 & & $\otimes$ & & & & & $\theta$ & & & & & $\otimes$ \\
\hline 102 & $\begin{array}{c}724 \\
K^{2}\end{array}$ & 10 & $\otimes$ & & 3 & 2 & & 6 & & $\theta$ & & & & & Q & 0 & 0 & & & $\theta$ \\
\hline 103 & $85 k$ & 8 & $\otimes$ & & 2 & $\otimes$ & & 3 & & & & & & & $\otimes$ & & & & & $\otimes$ \\
\hline 105 & $43 \pi$ & 6 & $\otimes$ & & 2 & $\otimes$ & & 2 & & . & & & & & & & & $\otimes$ & & \\
\hline 106 & $75 K$ & 10 & $\theta$ & & 2 & 8 & & 4 & & $\theta$ & & & & & $\otimes$ & & & & & 0 \\
\hline 109 & $\begin{array}{ll}109 \\
Z_{i}\end{array}$ & 4 & 8 & & 1 & 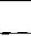 & $\otimes$ & 2 & $\otimes$ & & & & & & & & & $\otimes$ & & \\
\hline 110 & ${ }^{21 \%}$ & 8 & $\otimes$ & & 3 & $Q$ & & 4 & & & & & $\theta$ & & & & $\theta$ & & & \\
\hline 112 & $80 \mathrm{KL}$ & 5 & $\theta$ & & 1 & $\theta$ & & 2 & & & & & & & & & & $\theta$ & & \\
\hline 123 & $93 \mathrm{KL}$ & $y$ & $\theta$ & & $I$ & & $\otimes$ & 6 & $\theta$ & & & & & $\otimes$ & & & & $\otimes$ & & \\
\hline 114 & $36 \kappa$ & 8 & 8 & & 3 & & $\theta$ & 6 & $\otimes$ & & & & & & 0 & & $\otimes$ & & & \\
\hline 116 & 208 & 7 & $\otimes$ & & 2 & $\otimes$ & & 3 & 8 & $\theta$ & & & $\otimes$ & & & & $\otimes$ & & & \\
\hline Dy & 213 & 5 & $\theta$ & & I & $\otimes$ & & 2 & & & & & & & & & & & & $\theta$ \\
\hline 118 & ${ }^{112}$ & 11 & $\otimes$ & & 3 & $\otimes$ & & 4 & $\otimes$ & 8 & & & & & & & $\theta$ & & & \\
\hline 120 & $26 \mathrm{Ki}$ & 10 & $\otimes$ & & 2 & $\otimes$ & & 3 & & $\$$ & & & & & & & $\theta$ & & & \\
\hline 122 & $76 \pi$ & 7 & $\otimes$ & & 2 & $\otimes$ & & 3 & & & & & & & & & $\theta$ & & & \\
\hline 123 & $59 \mathrm{Ki}$ & 6 & $\otimes$ & & 2 & & $\otimes$ & 4 & & & $\otimes$ & & & & & & $\theta$ & & & \\
\hline 124 & $\begin{array}{c}7 \mathfrak{R}^{9} \\
\mathrm{~K}^{2}\end{array}$ & 8 & $\otimes$ & & 2 & $\theta$ & & 3 & & & & & $\theta$ & & & & & $\theta$ & & \\
\hline 126 & $60 \mathrm{~K}$ & 6 & 0 & & J & $\theta$ & & & $\theta$ & $\otimes$ & & & & & & & $\otimes$ & & & \\
\hline 129 & $94 \pi$ & 6 & $\theta$ & & 1 & $\theta$ & & & & & & & & & & & & & & $\otimes$ \\
\hline 131 & $79 k_{i}$ & 8 & $\theta$ & & 2 & $\otimes$ & & 5 & & $\otimes$ & & & & & & & $\theta$ & & & \\
\hline 132 & $37 K$ & 8 & 2 & & 2 & (2) & & 3 & & 8 & & & & $\theta$ & & & $\theta$ & & & \\
\hline 133 & 7ORi & 6 & 8 & & 2 & & $\otimes$ & 5 & & & & & 8 & & $\theta$ & & $\theta$ & & & \\
\hline 145 & $69 \%$ & 6 & 8 & & 1 & & $\theta$ & 5 & & & $\theta$ & & $\otimes$ & & & & $\theta$ & & & \\
\hline 146 & $\begin{array}{l}2 \overline{5} \\
\mathrm{Ri}\end{array}$ & 5 & $\otimes$ & & 1 & $\otimes$ & & 2 & & & & & & & & & 8 & & & \\
\hline 148 & $30 k$ & 7 & $\otimes$ & & 2 & & 8 & & $\otimes$ & & & & & & $\theta$ & & & & & $\theta$ \\
\hline 149 & $\begin{array}{l}128 \\
\kappa i\end{array}$ & 5 & 8 & & 1 & 8 & & 2 & & & & & & & & & & $\theta$ & & \\
\hline 150 & $\begin{array}{c}199 \\
K \mathrm{~K}\end{array}$ & 6 & & $\theta$ & 1 & & $\otimes$ & 3 & & & & & & & & & & $\theta$ & & \\
\hline 157 & $44 \kappa_{2}$ & 7 & 8 & & 2 & $\theta$ & & 5 & & & & & & & & & $\theta$ & & & \\
\hline 152 & $65 \mathrm{~K}_{\mathrm{i}}$ & 10 & $\otimes$ & & $5 \frac{1}{2}$ & $\otimes$ & & 6 & & & & & & & & $\theta$ & $\theta$ & & & \\
\hline 753 & $52 K \mathrm{~K}$ & $y$ & $\theta$ & & $?$ & & & 4 & 8 & & & & & & & & & & $\otimes$ & \\
\hline 155 & 182 & 6 & $\otimes$ & & 2 & $\theta$ & & 1 & & $\otimes$ & & & & & & & 8 & & & \\
\hline 157 & 227 & 7 & $\theta$ & & 2 & $\otimes$ & & 2 & & $\otimes$ & & & $\theta$ & & & & $\otimes$ & & & $\otimes$ \\
\hline 158 & $95 \mathrm{Ki}$ & 6 & $\otimes$ & & 2 & $\otimes$ & & 4 & & $\theta$ & & & & 8 & & & & $\theta$ & & \\
\hline
\end{tabular}

$25-5=3 g 82$ Atarelibtor:

skultur (Varn af smukke huse af bygningskulturel vardi, 5). Herifindes et fotografi af hvert hus, der er med på skemaet. 
eller 3 fag; men der er også eksempler på, at disse rum var $\mathrm{i}$ husets $ø$ stende. En del af husene har en nordfløj, der enten kan ligge ved vesteller østgavlen. Der er intet gammelt Rømø-hus, der har fløj mod syd. Fløjen rummer laden og loen. Antagelig omkring 1900 har en del huse fåt tilbygget et ca. $2,5 \times 2,5 \mathrm{~m}$ halvtags udhus med paptag. Det ligger også på nordsiden og ved den ene gavl.

Boligen bestod som regel af 1 . en forstue, framgulvet, mod syd, som kunne være gennemgående til en dør i nordsiden eller standse ved hovedskillerummet, 2 . et køkken mod nord, tidligere med et åbent ildsted og måske en bageovn, 3. en daglig opholdsstue, sønderdørns, tidligere med en bilæggerovn, der fyredes fra køkkenet, 4 . en anden opholdsstue, nørredørns, der måske kunne opvarmes, 5. æ pisel, æ kønne dørns, der ikke kunne opvarmes, og evt. 6. et kammer, der kunne ligge enten mod syd eller nord. Husdybderne varierer fra ca. 6,00 $\mathrm{m}$ til ca. 7,50 m, og det er de ældste huse, der har den mindste husdybde. ${ }^{1}$ De mindre huse kan være uden nørredørns og (eller) pisel. Loftrummet benyttedes udelukkende til opbevaring for avlen.

\section{Planlosningerne}

På grundlag af dette program er der udviklet nogle plantyper. Den for bl.a. Møgeltønder karakteristiske karnap findes der kun 3 eksempler på. ${ }^{2}$ Tværskillerummene stod ikke altid ind mod en bjælke, og der var ikke nødvendigvis et vindue $\mathrm{i}$ hvert fag, hvad der f.eks. kunne skyldes anbringelsen af alkover; men så var der gerne malet et blindt vindue på muren. Yderdørene fra stalden og loen sad altid midt i gavlen med et lille vindue på hver side. Mellem de bærende stolper sad vinduerne derimod vilkårligt.

Planerne er nu mere eller mindre ændrede. Hvis der kan findes frem til deres oprindelige udformning, skyldes det spor i lofter og gulve, hvor skillerummene tidligere var placerede. Der kan undertiden være mange spor, og de kan virke forvirrende, ligge tæt på eller krydse hinanden, så deres tidsmæssige rækkefølge vanskeligt kan afgøres. I mange tilfælde er både lofter og gulve fornyede, og så er mange beviser på den tidligere indretning forsvundne.

\section{Fagbredden}

Fagbredden er gennemgående $175-180 \mathrm{~cm}$ i boligerne og op til $230 \mathrm{~cm}$ i staldene og loerne. Det sidste sted var der ikke lagt loft, fordi der skulle kunne tærskes med plejl, og det er et arbejde, der kræver en vis højde. 

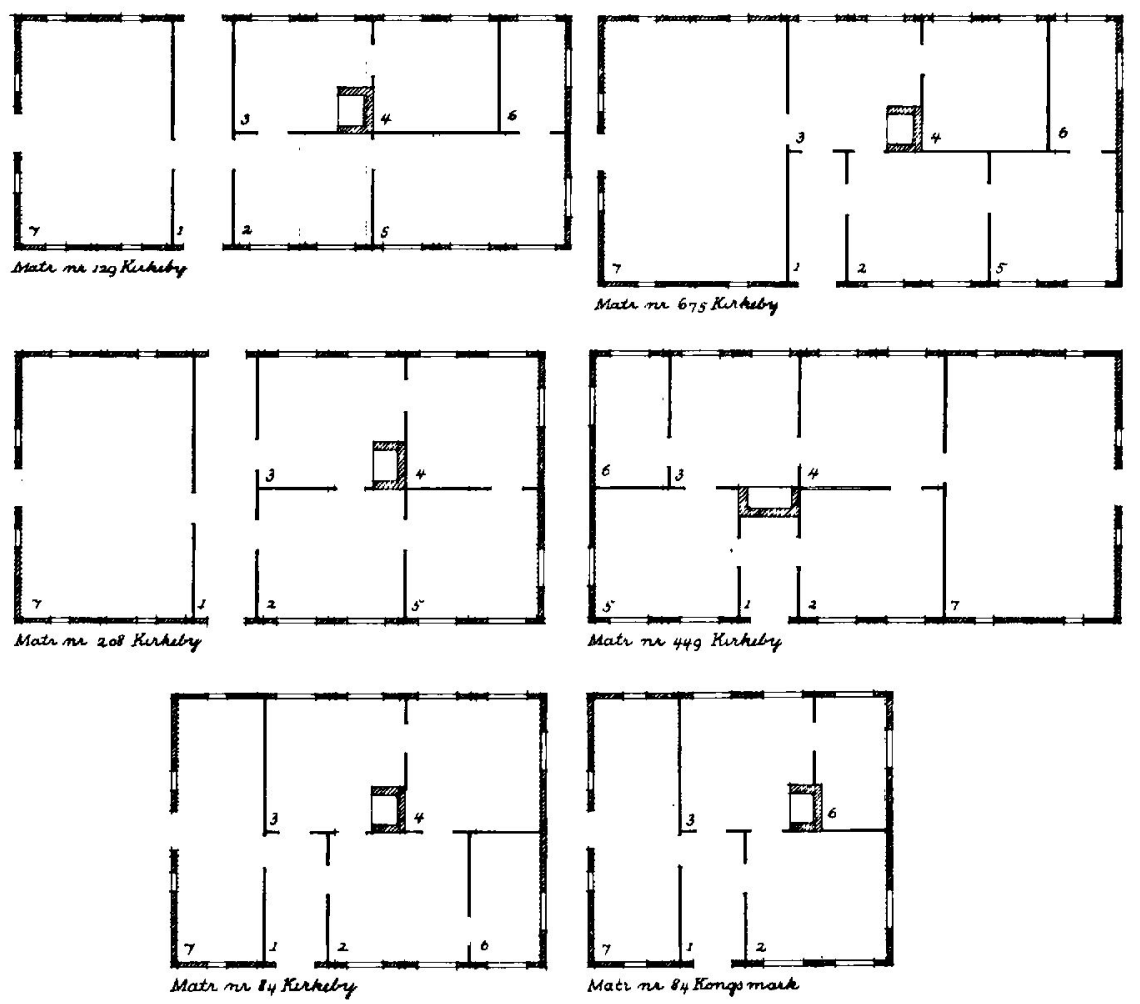

Grundplanstyper for Romohuse. Husene er overst fra venstre matr. nr. 129 Kirkeby, matr. nr. 675 Kirkeby, matr. nr. 208 Kirkeby, matr. nr. 449 Kirkeby, matr. nr. 84 Kirkeby og matr. nr. 84 Kongsmark. $-1=$ framgulv, $2=$ sonderdorns, $3=$ køkken, $4=$ norredorns, 5 $=$ pisel, $6=$ kammer, $7=$ stald og lo.

\section{Rumhøjden}

Rumhøjden er normalt omkring 190-195 cm til bjælkernes overkant, men der er huse, hvor den kun er ca. $180 \mathrm{~cm}$.

\section{Bindingsvark og grundmur}

Grundmur er en gammel konstruktionsmåde på øen; men der har tidligere være anvendt bindingsværk på mange huse, der nu er grundmurede.

At et hus oprindelig har været opført med stolper kan ses af flere forhold: 1. Mindst een stolpe er bevaret $\mathrm{i}$ facaden, 2. En gavlbjælke i plan med murens yderside er bevaret, 3. Murremmen er synlig og i plan med murens yderside, og den er evt. forsynet med naglehuller under 
bjælkehovederne, 4 . I bjælkernes underside er der ca. $30 \mathrm{~cm}$ fra murens inderside et udfyldt taphul, og på deres lodrette sider naglehul.

Det har ikke varet muligt at komme ind $i$ alle husene, og adskillige steder kan murremmen være skjult under mange lag kalk eller maling, ligesom bjælkernes tap- og naglehuller kan være gemt under en beklædning.

Benævnelsen bindingsværk er egentlig misvisende, for konstruktionen består kun af stolper, der for neden står på en stor sten og for oven er tappet ind i en murrem. Fodtømmer, løsholter eller dokker anvendes ikke. I 1892 var det karakteristisk, at Rømøhusenes gavle var grundmurede, og at langsiderne var af bindingsværk. ${ }^{3}$ Omkring århundredskiftet var også sydsiderne grundmurede. ${ }^{4}$

Ejendommen, matr. nr. 675, Kirkeby, kan oplyse en del om denne udvikling. Den var ifølge en brandforsikringsprotokol i Landsarkivet $\mathbf{i}$ Åbenrå i 1830 opført i bindingsværk. Nu er dette kun bevaret på halvdelen af husets nordside, og på østgavlen er der en synlig bjælke. På sydsiden, der synes grundmuret, ligger der en stor marksten lodret under hvert bjælkehoved, og der er fine revner i murværket ned til stenene. Under bjælkehovedet er der naglehul i murremmen. Stolperne er altså taget ud, og rillerne efter dem er muret til. Dette er et enligt tilfælde; men der er mange grundmurede huse, hvor murremmen er synlig og forsynet med naglehuller efter stolper.

Forklaringen på, at så mange Rømøhuse kun har stolper i nordsiden er, at enten er stolperne $i$ de andre sider taget ud, og rillerne efter dem muret til eller, at hele muren er fornyet på sin gamle plads. Hvor murremmen ikke er synlig, kan ydermuren være skalmuret udvendig eller helt fornyet. At gavlenes stolper er forsvundet først og nordsidens sidst skyldes, at de er mest udsatte for vejret, mens nordsidens er mindst udsatte. Da stolperne var af fyrretræ, kan de ikke have haft nogen lang funktionstid på gavlene og sydsiderne.

Stolperne står som nævnt på store marksten, hvis oversider er nogenlunde i plan med terrænet. Foroven er de tappet ind i en murrem, der er 8-12 cm høj og 12-15 cm bred. Her er forbindelsen sikret med trænagler. Bjælkerne er formodentlig forbundne med murremmen ved kæmning, der sikrer mod udskridning. Mellem stolperne og syldstenene mangler sikring, og mange ydermure er skredet ud for neden.

Skråafstivninger i længderetningen er der kun fundet få eksempler på, og de har næppe betydet stort på grund af deres korthed. Afstivninger i tværretningen, mellem stolperne og bjælkerne, er fjernet, da stolperne forsvandt. De har været af nogenlunde samme længde som 
Langdeafstivning $i$ matr. nr. 212 Kirkeby.

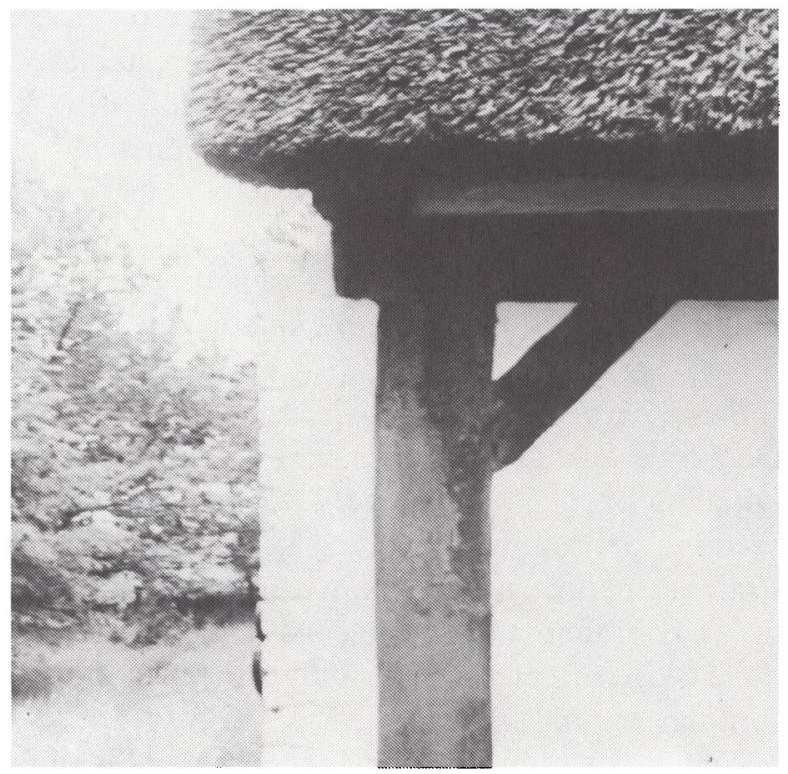

længdeafstivningerne og af samme ringe virkning. Deres spor ses som naglehuller i bjælkernes lodrette sider og som udfyldte taphuller i undersiderne, hvis ikke bjælkerne er blevet beklædte med brædder.

De stolpebyggede huse må have krævet en meget omhyggelig afstivning, indtil tavlene var muret op og loftplankerne lagt. Stolperne er normalt ca. $16 \mathrm{~cm}$ brede og $8-12 \mathrm{~cm}$ tykke.

Bjælkerne har $\mathrm{i}$ adskillige huse pilhøjde, en svag krumning, så der bliver højere til loftet ved hovedskillerummet end ved ydervæggen. Sådanne bjælker har muligvis en fortid som dæksbjælker i et skib. ${ }^{5}$ Der strandede tidligere mange skibe på Rømø, og måske har man også købt udtjente skibe til ophugning. Træet i de krumme bjælker er usædvanlig hårdt, og det er uden profiler på kanterne.

\section{Tagvarkerne}

Med enkelte undtagelser er tagene halvvalmede, og valmene er så store, at der kun er plads til en 70-90 cm høj gavllem mellem tagskægget og bjælkeoverkanten.

Der er ikke foretaget nogen egentlig undersøgelse af tagværkerne i forbindelse med denne redegørelse; men de, der er beset, viser tømmer af forskellige dimensioner og former i det samme hus. Der kan være 
både runde, savskårne og hugne spær og hanebånd i tagværket, og samlingerne er yderst primitive. Sådan har taget måske altid set ud, fordi rørtaget ikke kræver stor præcision af underlaget, men da der er foretaget udskiftninger af defekte konstruktionsdele samtidig med omtækninger, er der muligvis ikke ret meget tilbage af det oprindelige tagværk i et gammelt hus.

Spærenes forbindelse med bjælkerne er ikke undersøgt, men den består formodentlig i en tap i spærenden og et taphul i bjælkeenden.

\section{Gulvene og lofterne}

De gamle gulve og lofter er lagt af fyrreplanker, der kan være $3,5 \mathrm{~cm}$ tykke og op til $30 \mathrm{~cm}$ brede. De er ofte uden pløjning og af vekslende bredde i det samme gulv. Ved lægningen er der ikke brugt forløbende stød, alle plankerne er lige lange, og hvor de ikke har kunnet nå fra væg til væg, er der en stødfuge på tværs af rummet fra ydermuren til hovedskillerummet. Under gulvene er der stoppet fast med rent sand, som der er nok af.

I de små stalde har gulvene været en blanding af sten og træ. Der findes staldgulve med en stenstørrelse på $20-25 \mathrm{~cm}$. De er sejlet til øen, som ikke selv har sten. Staldgulvene er nu oftest fornyede eller overstøbte med cementmørtel, hvis ikke stalden er inddraget $\mathrm{i}$ beboelsen. Hvor de gamle huse er beboede af Rømøser, er staldene i mange tilfælde intakte, selv om landbruget er nedlagt. De bruges nu som udhusplads.

\section{Murerarbejdet}

Murerarbejdet i de gamle huse omfattede udmuringen mellem stolperne, opmuringen af overgavlene, skorstenene med ildsted og bageovn og opsætning af fliserne på ydervæggene.

Som fundament for tavlene kan der være anvendt håndstore marksten eller et murstensskifte, hvor stenene er lagt på tværs af tavlenes længderetning, så fundamentet bliver lidt bredere end murtykkelsen. Fundamentet går højst $10 \mathrm{~cm}$ ned $\mathrm{i}$ jorden (sandet), og der er ikke anvendt mørtel mellem markstenene. Når denne form for eller mangel på fundament ikke giver nævneværdig anledning til sætninger af murværket, men nok til udskridning af muren forneden, skyldes det den rene sandbund.

Murstenene er små, $8,5 \times 18 \times 4 \mathrm{~cm}$, hvor de er mindst. I nogle huse, hvor murene er omsatte, ${ }^{6}$ er der anvendt munkesten i de nederste skifter. Det er nærliggende at tænke på, at Trøjborg i Visby blev 
nedrevet 1854. De små mursten kan i murværket være en blanding af røde og gule, som er farvet røde. Murenes ydersider er i mange tilfælde bevarede med optrukne, hvide fuger, hvor der er grundmur. På især de mindre huse er murene mest berappede og (tidligere) kalkede.

Ydermurene var i stolpehusene kun $\frac{1}{2}$ sten tykke. Deres inderside var i beboelsesrummene beklædt med hollandske eller nordtyske fliser, der var sat op i skelkalk, som giver en meget stærkt mørtel, der gør det vanskeligt at tage dem ned igen, hvad mange senere har erfaret, når de solgte dem. I koldt vejr dannede der sig kondensvand på de tynde mure, og for at optage det, lagdes en række porøse mursten i gulvene langs ydermurene.

Fliserne er $13 \times 13 \mathrm{~cm}$, og hvor de endnu sidder på væggene, er der mange forskellige slags. Den flise, der ses tiest, er nok den bibelske, men der ses også billeder og figurer, der er sammensat af mange fliser. Desværre er mange fliser forsvundet fra de rømøske vægge de sidste 50 år.

\section{Bindingsvark og grundmur}

Stolpevæggen er en nøgtern konstruktion uden stilhistorisk præg, som den ses på Rømø. Grundmuren giver derimod mulighed for stilhisto-

Nordgavlen pd matr. 124 Kirkeby. 
risk udforming. Se f.eks. tegningen af gavlen på nordfløjen af matr. nr. 124, Kirkeby. Den bærer årstallet 1720; men man kan nu ikke stole på, at tallet er identisk med gavlens opførelsesår. Dens arkitektur viser længere tilbage $\mathrm{i}$ tiden. Det ses både på strømskifterne op langs taget og på de 2 dobbeltblændinger i overgavlen.
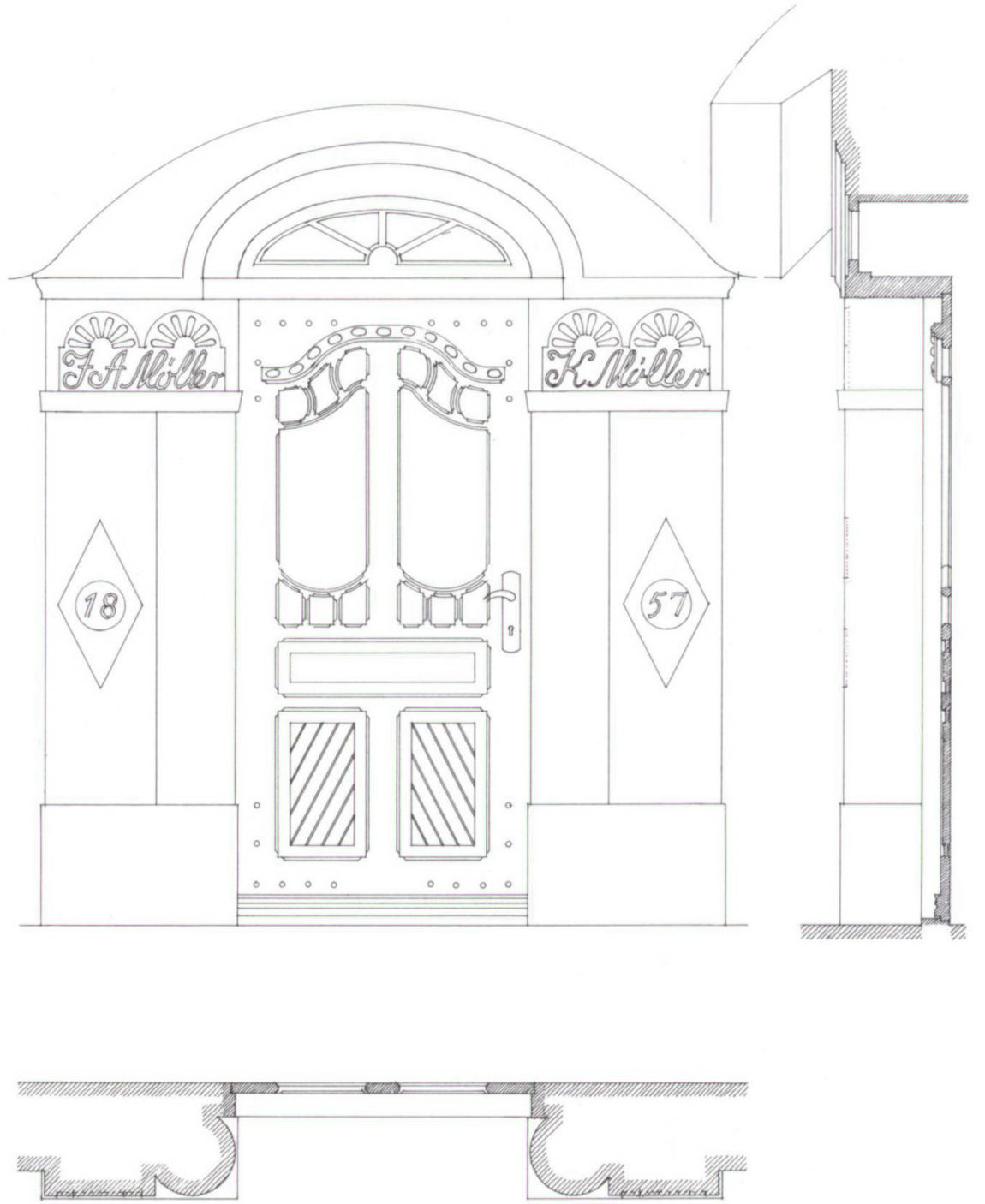

Indgangsportalen pd̊ gården matr. 44 Kongsmark. 
Når murremmen ikke ligger synlig på en grundmurs yderside, er der muret stik over vindues- og døråbningerne, og stenene kunne være malet i forskellige farver, f.eks. hvide, grønne og sorte, men denne bemaling ses nu sjældent. Stikkene kan være lige eller svagt buede. På ét hus er der anvendt formsten i forbindelse med de buede vinduesstik på østgavlen. ${ }^{7}$

På langsiderne af de grundmurede huse kan der være en 4 eller 5 skifter høj gesims med meget svagt fremspringende led, der kan fortsætte ca. $0,5 \mathrm{~m}$ om på gavlene, hvor den også forløber op langs taget og halvvalmens tagskæg. Sidst i forrige århundrede cementpudsedes (også på nogle af de gamle huse) profilerede indfatninger om vinduerne og yderdørene, og der kom sålbænke under vinduerne. ${ }^{8}$ Nordsiderne med deres bevarede stolpevægge er dog undtaget herfra. Hvor murremmene var synlige på murenes ydersider, blev der flere steder malet vindues- og dørstik op over den, og under vinduerne maledes sålbænke, for at de gamle huse kunne se moderne ud. ${ }^{9}$

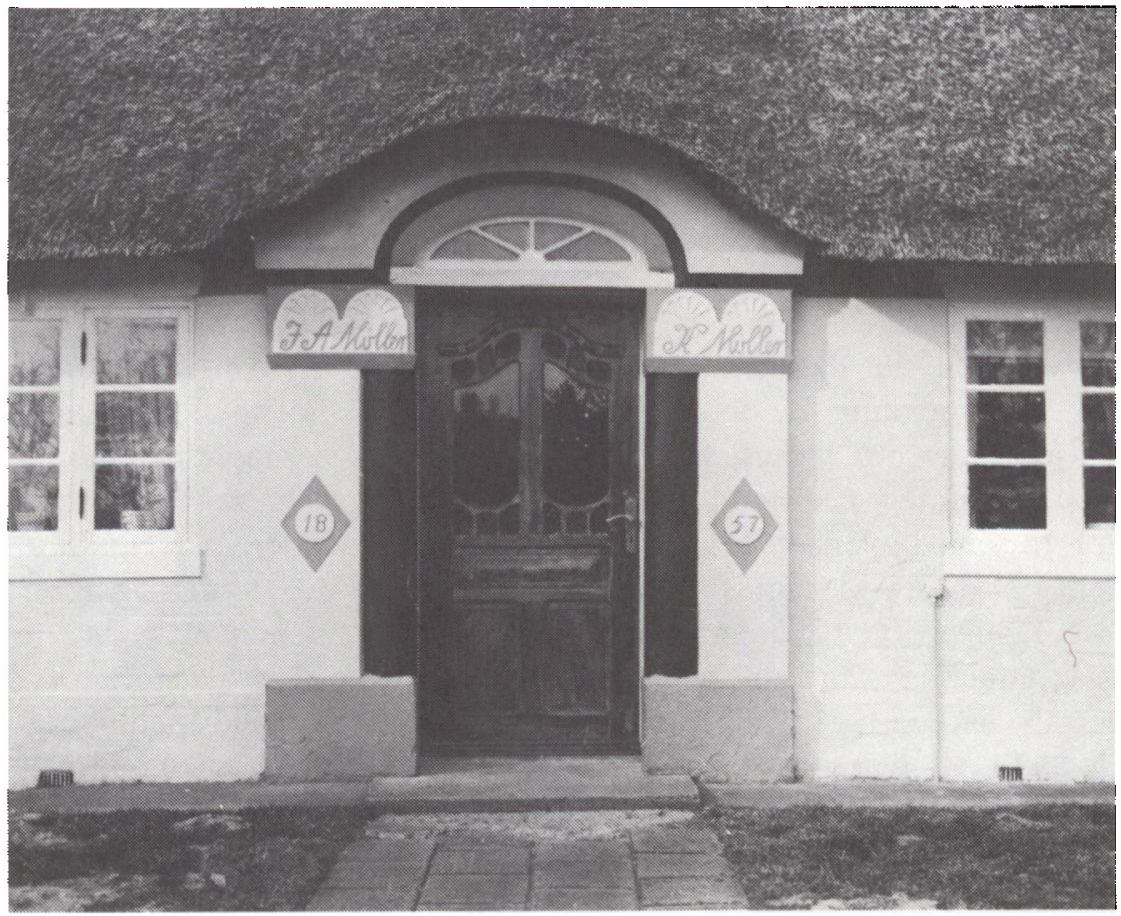

Portal og indgangsdør til matr. nr. 44 Kongsmark. 


\section{Portalerne}

Fra midten af 1800-årene fik mange Rømøhuse, også de ældste, tilføjet en detalje, som er særlig for øen, nemlig portalerne omkring indgangsdørene på sydsiderne. Der er henved 20 tilbage, og heraf sidder flertallet på de almindelige huse. Det er sandsynligt, at der også har været portal på en del af de nedbrudte huse. En af portalerne sidder på gården matr. nr. 44, Kongsmark og bærer årstallet 1857 samt forbogstaverne og efternavnene på det daværende ejerpar. Denne portal er nærmere den traditionelle arkitekturs former end de fleste andre på øen, hvoriblandt nogle er meget utraditionelle og fantasifulde i deres udformning, men fulde af humør. Trekvartsøjlen ind mod dørhullet findes på flere af portalerne. Desværre ved man ikke, hvem der er ophavsmand til denne usædvanlige mode.

\section{Indendors arbejde}

Inde $\mathrm{i}$ husene indskrænkede murerarbejdet sig som nævnt til skorstenen med det åbne ildsted, den eventuelle bageovn og fliseopsætningen. Ildstederne var af den vestjyske type, hvor kogestedet optog hele pladsen, og man derfor stod foran dem. Der er kun få ildsteder bevaret, og skorstenene er så godt som alle fornyede i moderne format. Af bageovne er der kun fundet én; men der er endnu nogle mennesker på øen, der kan udpege, hvor bageovnen stod i deres hus for indtil 25 år siden.

\section{Tagtakningen}

Tagene er tækket med tagrør, på Rømø kaldet istag, fordi rørene høstes om vinteren, når der er is på vandet, de gror $i$. Tagtykkelsen er ca. 30 $\mathrm{cm}$ ved nytækning, og der bindes med kokosreb. For mange år siden brugtes halmreb. ${ }^{10}$ Tagskægget skæres vandret af, og tagfladen har en svag krumning ned mod det. Rygningen lægges af lange strimler græstørv med overlæg fra øst mod vest, så vestenvinden ikke kan løfte dem, når de er nyoplagte. I løbet af nogen tid gror de sammen og ligger fast. Tidligere blev strimlerne lagt direkte på rørtaget; men nu lægges de på et underlag af tagpap. Ved valmene sluttes af med meget store tørv, der går ned ad taget som en tunge og fæstnes til det med træpløkker. Hen ad tagfladen sikres rygningstørvene med ca. $30 \mathrm{~cm}$ lange bøjler af ugalvaniseret hegnstråd. Der tætnes også med græstørv mellem skorstenen og tagfladen. I de seneste år er rygningerne yderligere stabiliserede ved, at de overtrækkes med hønsenet. Når der omtækkes, tages kun et stykke ad gangen. Så bliver der tid til at samle den nødvendige 
rørmængde, og omkostningerne ved arbejdet bliver mere overkommelige.

\section{Vinduerne og yderdorene}

Vinduesstørrelsen på de ældste huses beboelser er meget ensartet fra hus til hus. Højden er ca. $80 \mathrm{~cm}$, bredden ca. $100 \mathrm{~cm}$. Karmene sidder $i$ plan med murenes yderside. Rammerne har 2 ruder i bredden og 3 i højden. Et sted, hvor vinduerne er fornyet for ca. 150 år siden, er de gjort $10 \mathrm{~cm}$ højere med samme rudeinddeling. Der findes et par eksempler på, at de lodrette sprodser er udeladte ved rammernes fornyelse, så ruderne er blevet aflange $\mathrm{i}$ bredden, ${ }^{11}$ og der er adskillige huse fra 1800-årene, hvor der er 3 ruder i hver ramme, hvor vindueshøjden er større end bredden, og hvor rumhøjden også er blevet større. ${ }^{12}$ Et par huse har vinduesrammer med 2 ruder $\mathrm{i}$ højden ${ }^{13}$; men der er intet eksempel på et gammelt hus med 8 ruder i rammen. Rammerne er hængslet på posten, som er sværere end normalt. Til gengæld er

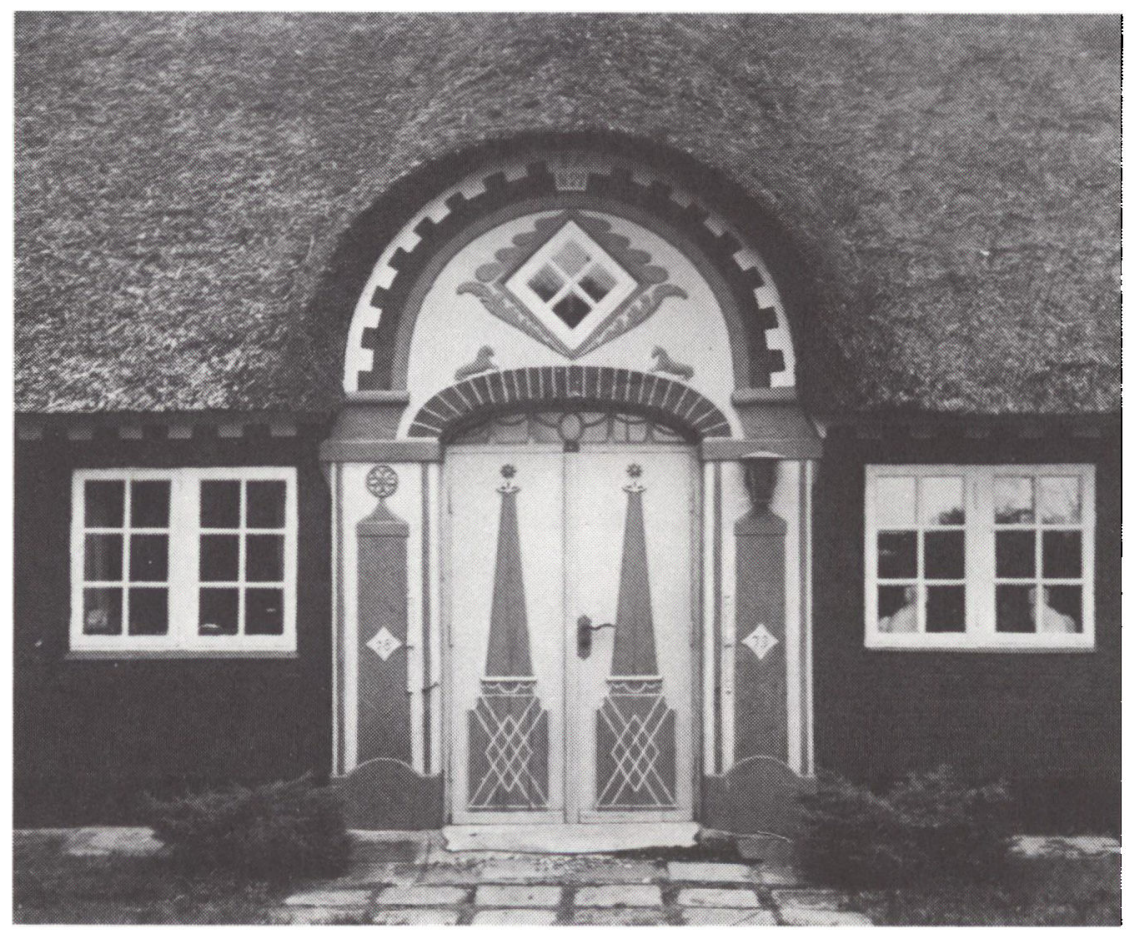

Portal og indgangsdor fra matr. nr. 32 Kongsmark. 
karmene spinklere. Formodentlig har der engang været vinduesrammer med blyindfattede ruder; men de er $\mathrm{i}$ hvert fald nu forsvundet.

Staldvinduerne er nu tiest af støbejern; men en del af dem er etrammede, af træ og med rudeinddeling som beboelsens rammer. Oprindeligt har der formentlig været glugger.

Yderdøren på matr. nr. 32, Kongsmark var før fornyelsen antagelig den ældste på øen. Den nuværende dør, som ses på billedet, er en kopi af den gamle, som endnu er bevaret. De fleste ældre framgulvsdøre, som er bevaret, er i tysk nyrenæssance, men der findes også et eksempel på jugendstilen. De udvendige framgulvsdøre er ofte fløjdøre. Stalddørene er altid enkeltdøre, og gamle halvdøre findes ikke.

\section{Indvendige dore}

Inde $\mathrm{i}$ husene findes endnu mange gamle døre fra forskellig tid. De er lavet af spinklere planker end nutidens døre, fra $2,2 \mathrm{~cm}$ til $2,8 \mathrm{~cm}$, så de kan ikke beslås med indstukne låse. Rammebredden er til gengæld større end på moderne fyldingsdøre, fra 12 til $20 \mathrm{~cm}$. Døren i vestvæggen i sønderdørns (matr. nr. 126, Kirkeby) findes som type i adskillige huse, men der er kun fundet en i hvert hus, og bortset fra den viste sidder de i køkkenerne. Typen er kendt fra flere steder i Sønderjylland. Den sidder f.eks. mellem forrummet og officinet på apoteket $\mathrm{i}$ Tønder.

\section{Traskillerummene}

Oprindelig var der kun træskillerum i de gamle huse, og mange af dem er stadig bevarede. De er normalt udført af $3,5 \mathrm{~cm}$ tykke og op til $30 \mathrm{~cm}$ bredde planker, der er høvlede og med profiler på kanterne. De kan være notet sammen, så hver anden planke springer frem, men der er også eksempler på brede planker, der veksler med smalle, og der er fyldingspaneler, hvor fyldingerne når fra gulvets til loftets rammestykke. De lodrette rammestykker kan være udformet som pilastre med baser og kapitæler. Når der i gamle dage skulle holdes en stor fest i et gammelt hus, nedtog man undertiden en panelvæg, så 2 rum blev slået sammen, og efter festen blev den sat op igen. ${ }^{14}$

\section{Alkoverne og de faste skabe}

Alle sengestederne var oprindelig i alkover. De var $160-170 \mathrm{~cm}$ lange og 120-125 $\mathrm{cm}$ brede. Et sted havde alkoven adgang fra begge langsiderne. Lågerne i dens bagside var dog kun revlelåger. Det har 
nok været en speciel ordning. Fælles for mange alkover er, at der til venstre $\mathrm{i}$ forsiden nær loftet er et lille skab, „brændevinsskabet«. Vandrette rammestykker er uprofilerede på den kant, lågerne er overfalsede på, selvom disse ikke spænder over hele forsidens bredde. Det skyldes, at man endnu ikke kendte kontrakehlingen.

Skabene kan findes i spildpladsen over bageovnens langsider, de kan hænge frit på væggen, eller de kan være indbyggede og nå fra gulvet til loftet og have 2 låger $i$ højden. Hvis et sådant skab findes i et opvarmet rum, kan dets øverste halvdel have været det sted, hvor mælken sattes for at trække fløde. Skabene har ofte svunget overramme og et sprodsedelt vindue.

\section{De udendørs farver}

Stolperne, murremmene og vindskederne kunne være strøget med finsk tjære. Når de udvendige murflader ikke stod i blank mur, var de kalkede. De små huse var oftest hvide, sjældnere gule, og et var indtil omkring 1960 gråt. ${ }^{15} \mathrm{Et}$ andet hus er opført i rød, blank mur med hvide fuger. Omkring 1900 var det gulkalket, og 1930 var det rødkalket. ${ }^{9}$ Det er ikke nu muligt entydig at fastslå, hvordan husenes facader har været behandlet gennem årene; men det har ikke været en ubrydelig tradition, at de skulle være røde. Imidlertid er denne opfattelse nu i den grad slået igennem, at der $\mathrm{i}$ byplanvedtægten for visse sommerhusområder på øen stilles krav om, at facaderne skal behandles med »rømørødt «. Hvordan denne farve ser ud, er ikke nærmere defineret. I de senere år anvendes mest et fabriksfremstillet produkt i stedet for kalk til udvendig behandling af murfladerne, ja, en husejer har endda malet sit hus med rød skibsmaling. De moderne behandlinger af murfladerne er en stoflig forringelse $\mathrm{i}$ forhold til kalkningen, men det må erkendes, at denne er en større økonomisk belastning end malingen, der holder længere.

Skorstenspiberne er normalt behandlet som facaderne, men der er en del piber med hvidt skaft og rød sokkel og hoved. De er måske ment som en demonstration i den tyske tid.

\section{Malerarbejdet}

Vinduerne, de udvendige døre og portene er oftest malet hvide, men hvis der skrabes på den hvide maling, kommer der grøn farve frem på vindueskarmene, dørene og portene.

De oprindelige farver på snedkerarbejdet inde i husene er dækket af mange lag maling, så noget generelt kan der ikke siges om dem. I huset på matr. nr. 675, Kirkeby, er der foretaget nogle undersøgelser, som 
kan oplyse lidt om farverne der, men noget sikkert resultat fra de enkelte rum kan der ikke fås. \#ndringer i grundplanen har bevirket, at nogle døre har skiftet plads, andre er måske kommet fra et nedbrudt hus, et loft er fornyet for 150 år siden, og panelerne $\mathrm{i} \mathfrak{x}$ pisel er fornyede på samme tid. Sådanne forhold gør det vanskeligt at få et samlet, sandfærdigt billede af farverne frem. Her var døre og paneler $\mathrm{i} æ$ pisel malet blå med lysere rammestykker og mørkere fyldinger. Dørenes profiler var stafferede med en lys, hvidblå farve, og loftet var lysegråt med en svagt grønlig tone. Dette rum var nyindrettet omkring 1830. Sønderdørns var mørkegrønt på døre og lofter, og køkkenet, det tidligere nørredørns, havde blå paneler, rødt loft og røde vinduer. Disse 2 rum skønnedes at stamme fra husets opførelse 1738 . I de øvrige rum kunne der ikke udledes nogen fællesnævner for farverne. $Æ$ pisel, sønder- og nørredørns blev nymalede med de fundne farver som grundlag, og der var ingen af en moderne fabriks mange farver, der kunne bruges, så blandingerne måtte foretages på stedet, og der blev selvfølgelig kun anvendt oliefarver. Der blev ikke fundet dekorationer på malerarbejdet i dette hus. I huset matr. nr. 117, Kirkeby, er foretaget nogle spredte afrensninger på det indvendige malerarbejde, og der er fundet marmoreringer, som gør det sandsynligt, at maleren fra Nationalmuseets kommandørgård har malet der.

Desværre interesserer for mange sig for tiden for at rense al gammel maling af snedkerarbejdet frem for at restaurere den.

\section{De hvide stakitter}

Endnu findes hvide stakitter ved mange Rømø-huse. De står nogle få meter fra sydfacaderne og er ca. $1 \mathrm{~m}$ høje. Hvor de slutter til gavlene, stiger højden op til husets tagskæg. De skulle holde løsgående dyr ude fra den lille have og give lidt læ for vestenvinden. Stavspidserne kan undertiden være fint svejfede. ${ }^{16}$

\section{Husene fra ca. 1860 til ca. 1890}

Husene fra denne periode er ikke typiske for Rømø alene. De er som samtidige huse andre steder i Sønderjylland; men på Rømø er de iøjnefaldende på grund af deres symmetriske facader. ${ }^{17}$ Indgangsdøren sidder nu midt på sydfacaden med et et-rammet vindue på hver side. Over døren er der gerne en 2-fags frontespice og omkring den en beskeden portal eller indfatning. Ydermurene er opført af røde mursten med hvide fuger og er afsluttet med en muret gesims, der er rigere og med større udladning end de gamle gesimser. Vinduerne har 3 ruder $i$ 

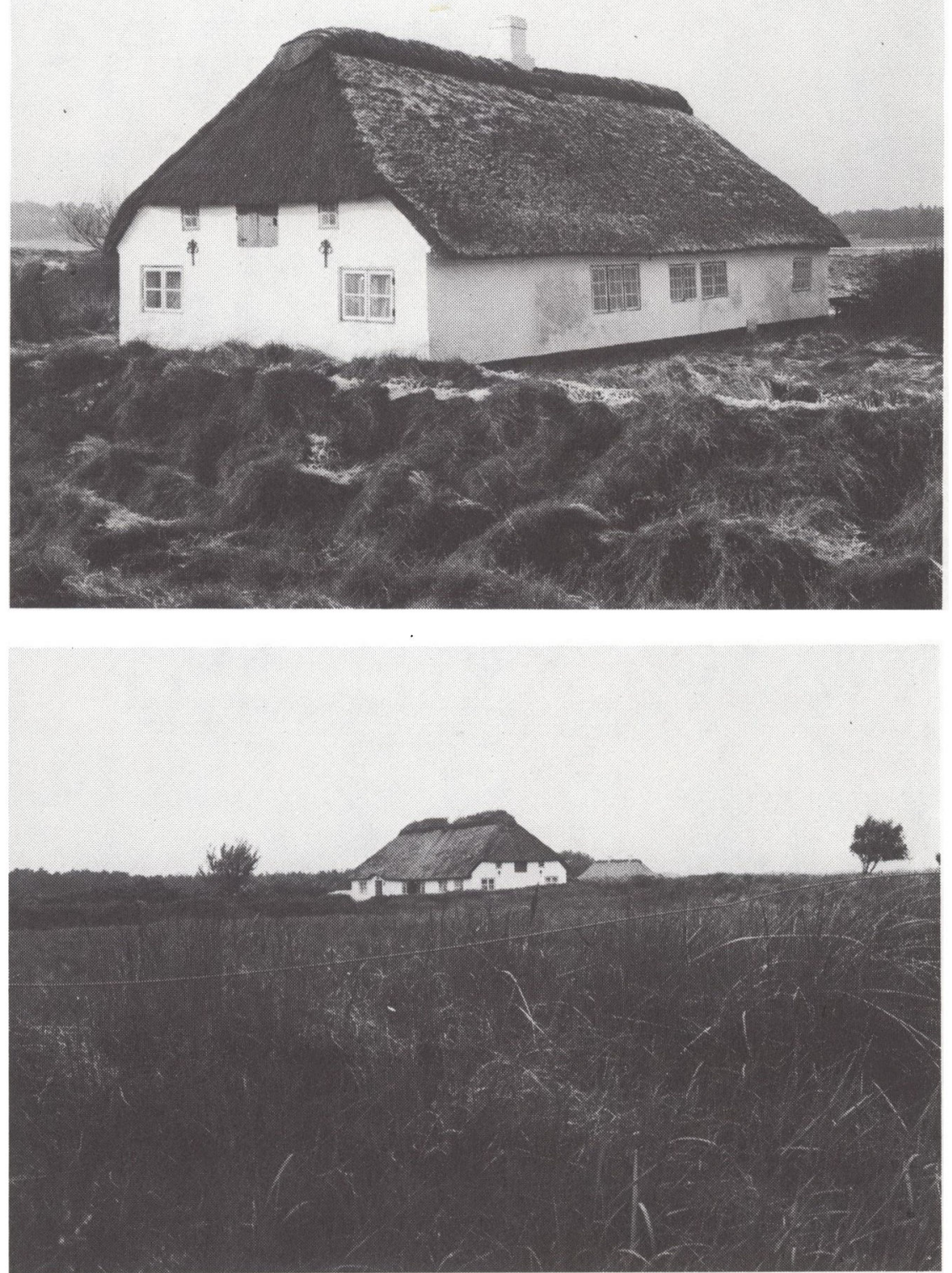

Matr. nr. 126 Kirkeby set fra nordøst (øverst) og fra sydøst (nederst). 

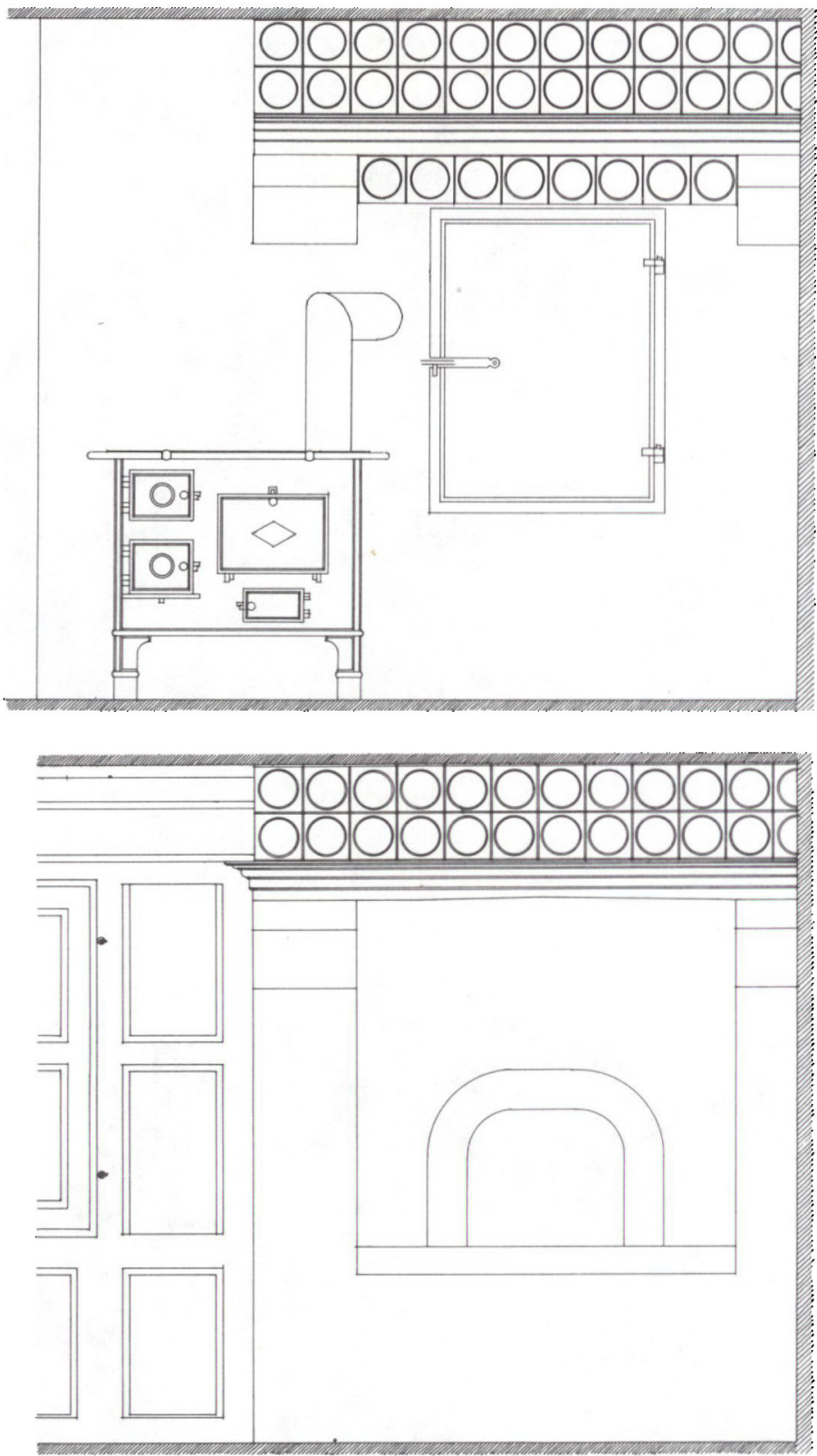

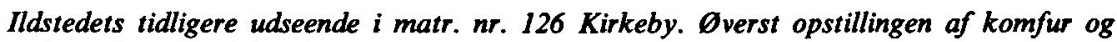
nederst den oprindelige konstruktion. 


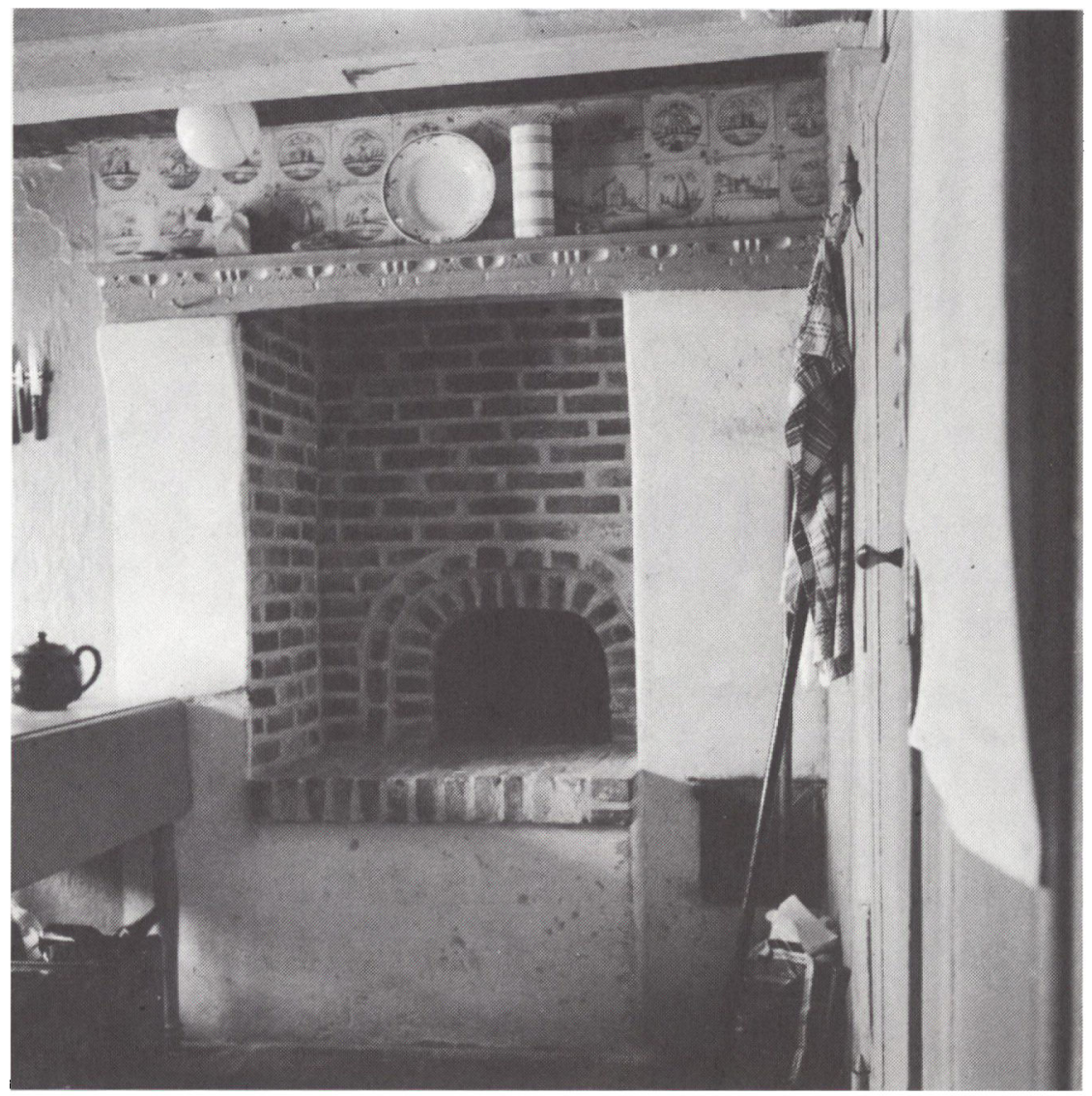

Ildstedet $i$ dag i matr. nr. 126 Kirkeby. Komfuret er nu fjernet igen.

hver ramme, og etagehøjden er blevet væsentlig større end i de gamle huse. Der bruges endnu undertiden fliser på indersiden af ydermurene; men de er dekoreret med et maskinpræget mønster, der ligner de gamle flisers, eller de er udekorerede. Formatet er endnu $13 \times 13 \mathrm{~cm}$.

Facadernes symmetri bevirker, at der kan komme almindelige vinduer ind til staldene, og at det traditionelle planskema ikke mere følges.

Matr. nr. 126, Kirkeby

Gennemgangen af Rømø-husenes fællestræk skal her afsluttes med en beskrivelse af et enkelt hus: matr. nr. 126, Kirkeby. 
Dette hus har i en sjælden grad undgået forandringer, siden det blev feriehus. Med de ændringer, tiden før århundredskiftet har mærket det med, med sine bygningsdele af forskellig alder og oprindelse er det dog et smukt og harmonisk hus. Dertil kommer, at det hviler karakteristisk i landskabet. Den grund, der hører til ejendommen er uden træbevoksning, som hele Rømø var det for 100 år siden.

\section{Planen}

Huset indeholder et framgulv mod syd, et køkken mod nord med et åbent ildsted og en bageovn, et sønderdørns, en pisel mod syd, et nørredørns og et kammer mod nord. Fagbredden er ca. 175-185 cm. De 2 vestlige fag er ca. $200 \mathrm{~cm}$ brede. Det østligste $215 \mathrm{~cm}$, hvilket kunne tyde på, at stalden først var planlagt her; men piselens bjælker er profilerede på de frie kanter. De kan naturligvis være beregnet til østenden af huset.

\section{Konstruktionen}

På nordsiden er bevaret 3 stolper, og på begge langsiderne er der et naglehul i remmen under hvert bjælkehoved. Huset er altså oprindelig opført i bindingsværk, der senere er udskiftet med grundmur. Vestgavlen og sydsiden synes udført samtidig. Murværket her er omhyggeligt udført og fuget. Måske har disse 2 sider stået i rød mur og hvide fuger.

Indgangspartiets nuværende form med fremspring fra facadens plan og de 2 små led, der ikke når tværs over pillebredden, ændring $\mathrm{i}$ murværket ved døren og buen i tagskægget tyder på, at der har været en portal, måske i lighed med den på matr. nr. 44 i Kongsmark.

Huset er enestående ved, at både det åbne ildsted og bageovnen er bevaret. Ildstedet er lidt andret i højre side efter opførelsen af en ny skorsten, og det kan ikke fungere mere. Over det er indmuret en egetræsbjælke, hvorpå der er fastgjort en profileret gesims, hvis udskæringer synes ældre end huset. Bjælkens underside bærer mærker, der viser ildstedets oprindelige bredde. I »komfuralderen« blev det lukket mod køkkenet med murværk og en jernlåge, som gjorde det muligt stadig at bruge bageovnen, og der blev opstillet et komfur med røgrør ind $\mathrm{i}$ ildstedet. ${ }^{18}$

Flere af husets bjælker har pilhøjde, så det er muligt, de stammer fra et skib. Alle loftbrædderne er fornyede, så eventuelle spor efter ændringer i planen er forsvundet. Enkelte gamle gulve er bevarede. 


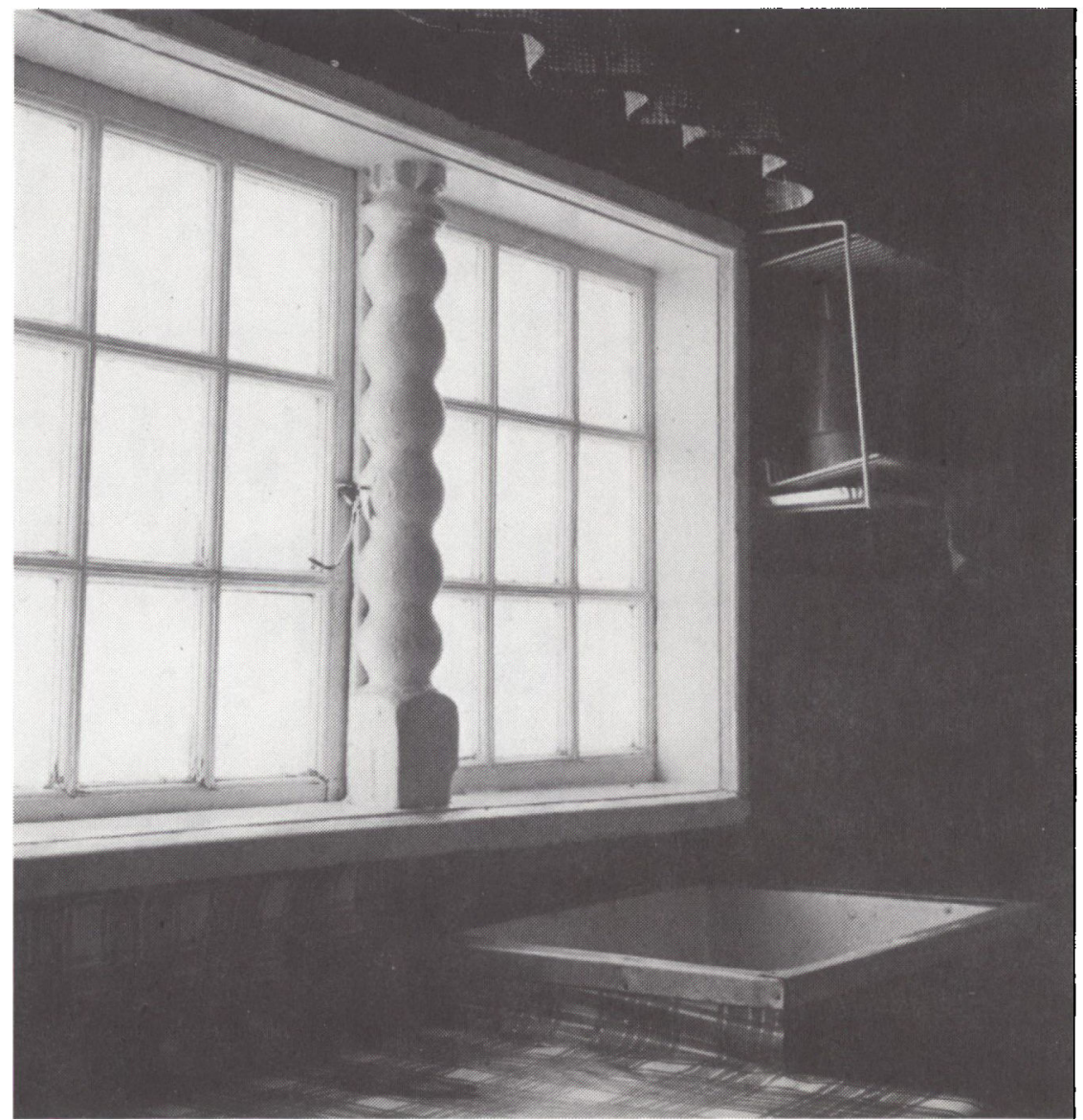

Kokkenvindue i matr. nr. 126 Kirkeby.

\section{Vinduerne}

Køkkenvinduerne er enestående på Rømø. De er næppe udført til huset, da karmene er $14 \mathrm{~cm}$ brede og muren, de sidder i, er $10 \mathrm{~cm}$ tyk. Hvis deres anbringelse var oprindelig, ville der heller ikke være et murstensskifte mellem overkarmene og murremmen. De små, nederste vinduer $\mathrm{i}$ vestgavlen, med skrå tilsætning til sidekarmene, kan være udført til huset, da gavlen blev ommuret. Snedkeren kan have glemt, at vinduer nu blev rykket tilbage fra murens plan, og derfor rager de frem på murens inderside. Alle de øvrige 6-rudede og de 4-rudede vinduesrammer er forholdsvis nye. 


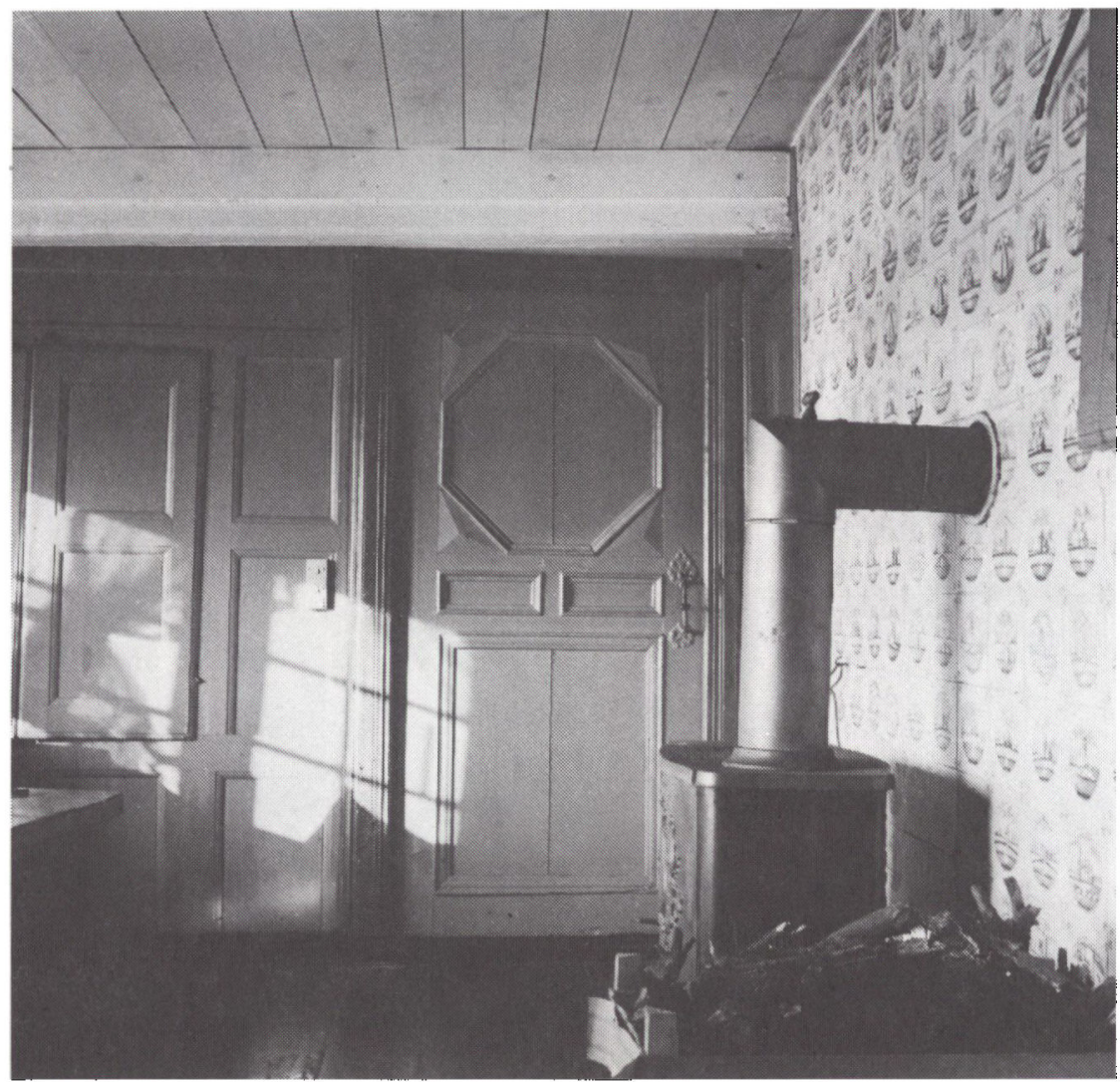

Dør $i$ vestvaggen $i$ sonderdorns $i$ matr. nr. 126 Kirkeby.

De indvendige dore

De 2 døre i piselens nordvæg er ens; men husets øvrige døre er forskellige. Døren fra sønderdørns til framgulvet er tidligere omtalt. Den har en fint profileret indfatning på siden mod sønderdørns, og på døren mellem piselen og det nordre kammer sidder en indfatning, som burde sidde på den anden side af karmen. Den synes at være hentet fra et fornemmere hus. De andre døre mangler indfatninger, eller disse er uden interesse.

\section{Traskillerummene}

Piselens skillerum er kommet fra huse, hvor der har været højere til loftet end her. De er også tilpasset i længden, og de er ikke samtidige. 


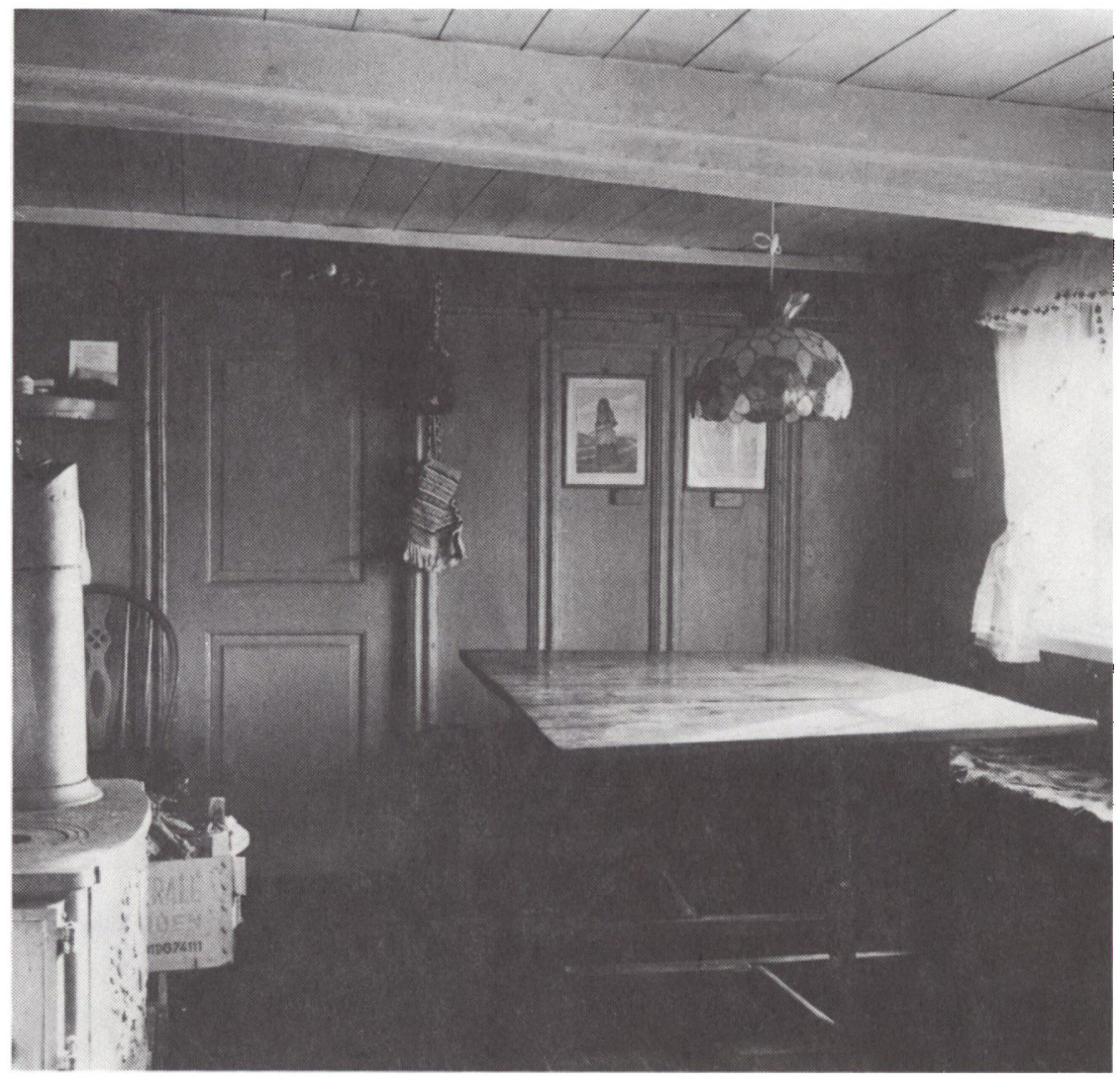

Ostvag i senderdorns $i$ matr. nr. 126 Kirkeby.

Skillerummet mod sønderdørns er afkortet for oven og for neden og øget mellem døren og bageovnen. Skillerummet mod de 2 nordlige rum er afkortet for neden og øget mod bageovnen.

Alkoverne og de faste skabe

Forstillingerne på husets alkover synes udført til andre pladser end dem, de nu har. Alkoven i sønderdørns er forhøjet, og dens venstre side er passet til den hældende ydermur.

Forstillingen passer i højden og langden i køkkenet, dersom den anbringes mellem ydervæggen og ildstedet, og hvis det faste skab, som ikke er oprindeligt, fjernes. Køkkenalkovens forstilling er beskåret $\mathrm{i}$ højre side, og hele den væg, den sidder $i$, virker sammenstykket. Selve 


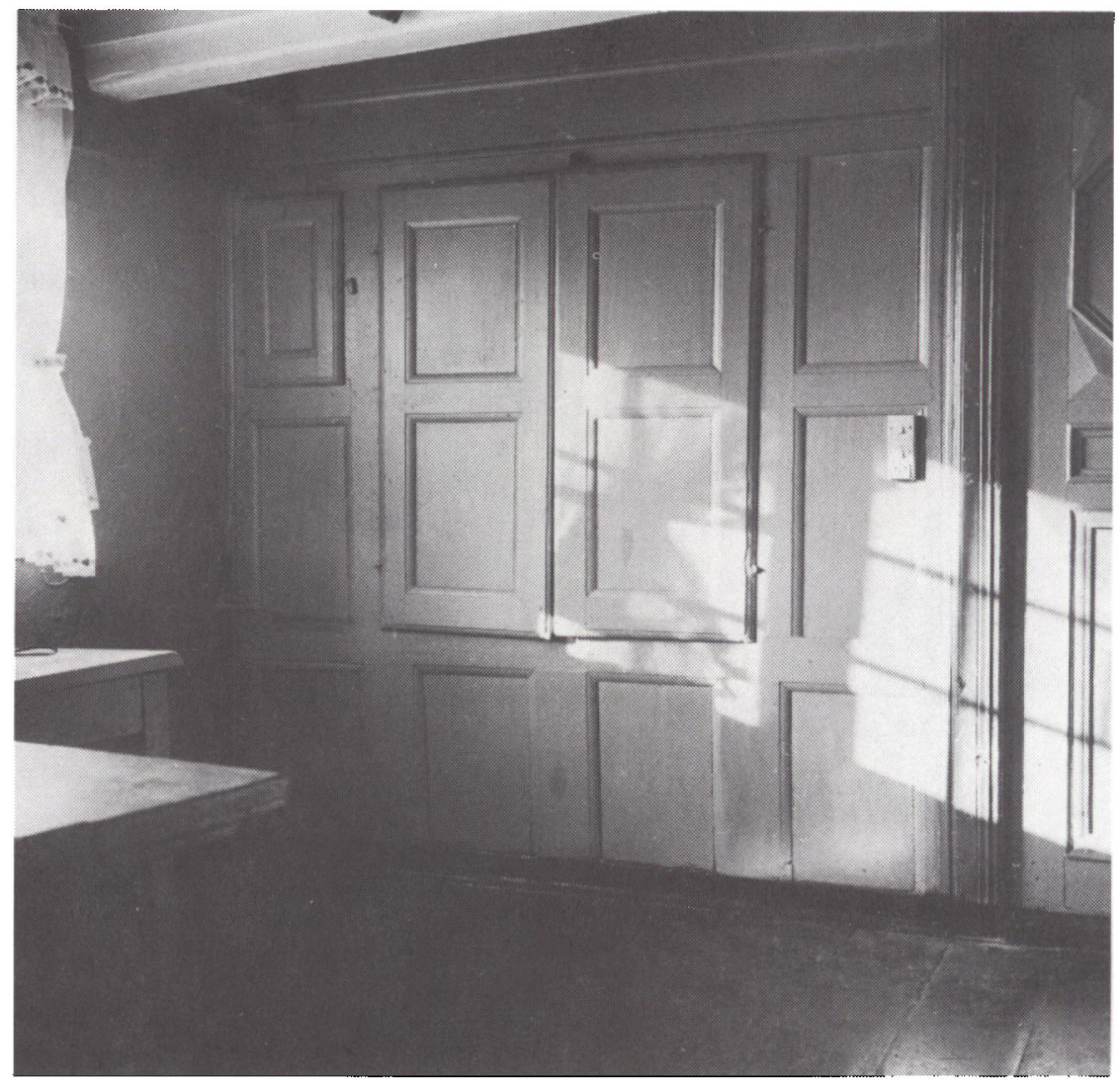

Alkove pd vestvaggen $i$ senderdorns i matr. nr. 126 Kirkeby.

forstillingen synes opbygget af dele, der har været anvendt $i$ anden sammenhæng, og den er stillet tæt op ad en bagved liggende bjælke, der stærkt formindsker den frie åbning bag de øverste låger.

Glaslågen i midten af det lille vægskab i sønderdørns er ikke udført til rammen, det sidder i. Der er sket en påforing, og der er spor efter andet beslag på lågen.

\section{Sammenfatning}

Der er på Rømø bevaret mange gamle huse, som det må være en opgave at værne om. De fleste af disse huse har nu udenøs ejere, som kun benytter dem til ferie- $o g$ fritidsophold, og det betyder desværre, at 


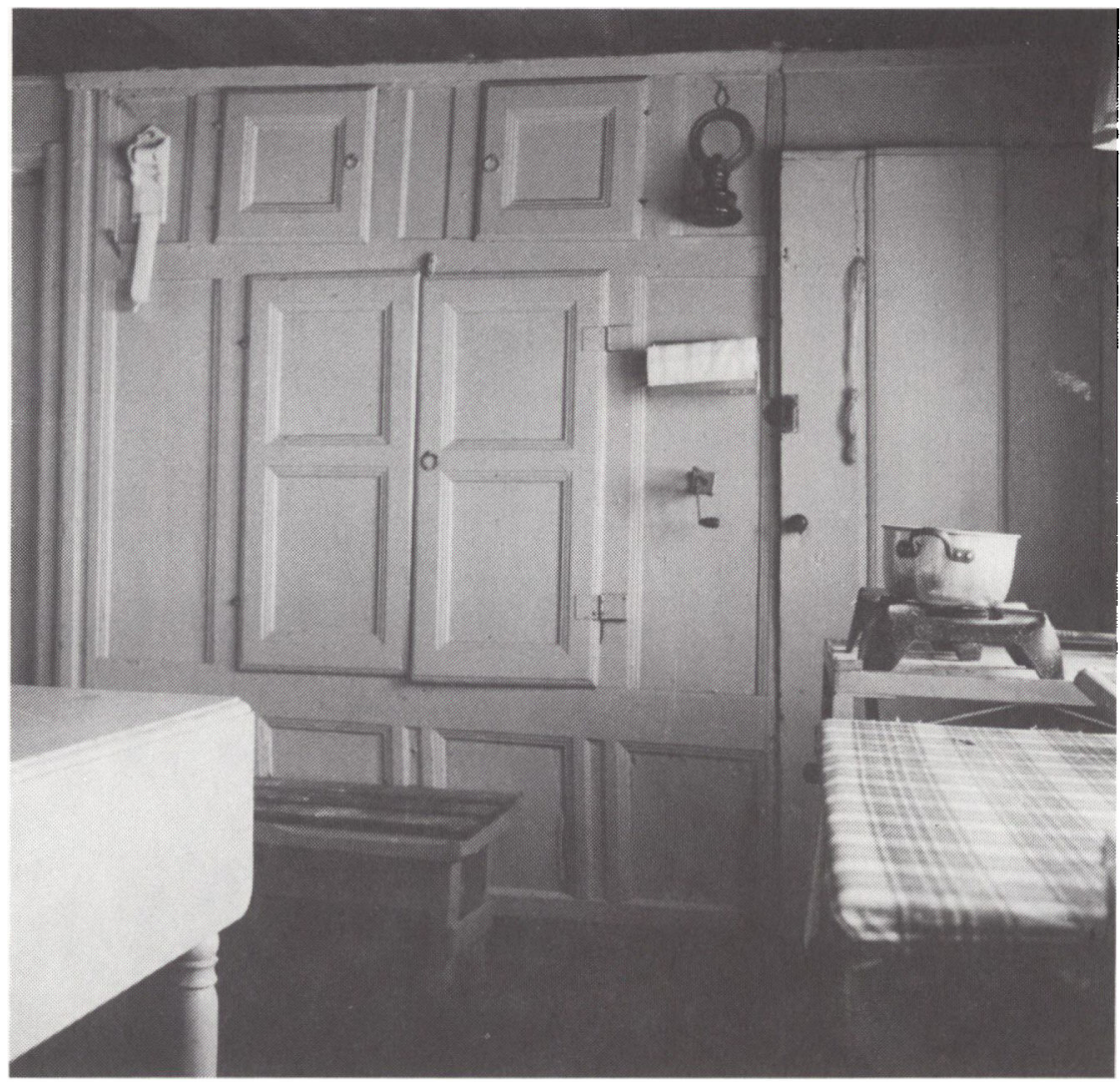

Alkove pd kokkenets vestvag i matr. nr. 126 Kirkeby.

de og deres omgivelser ligger »livløse« den største del af året, men det betyder til gengæld også, at de er blevet reddet fra nedrivning.

I de senere år er der sket mange forandringer ved husene og deres omgivelser. Det er jo almindelig anerkendt blandt tilhængere af bevaring, at de gamle huse skal kunne bruges af nutidens mennesker. Det kan de også efter en nænsom restaurering, hvor yderliggående modernisme og overdreven romantisering undgås. Det kan desværre ikke altid siges, at disse to skær er undgået.

Ejerne af de gamle huse samt offentlige myndigheder bør gå aktivt ind for bevaring - også af samspillet mellem landskabet og bebyggelserne - inden det er for sent. Det er ikke mindst dette samspil, der gør øen til noget enestående i Danmark. 


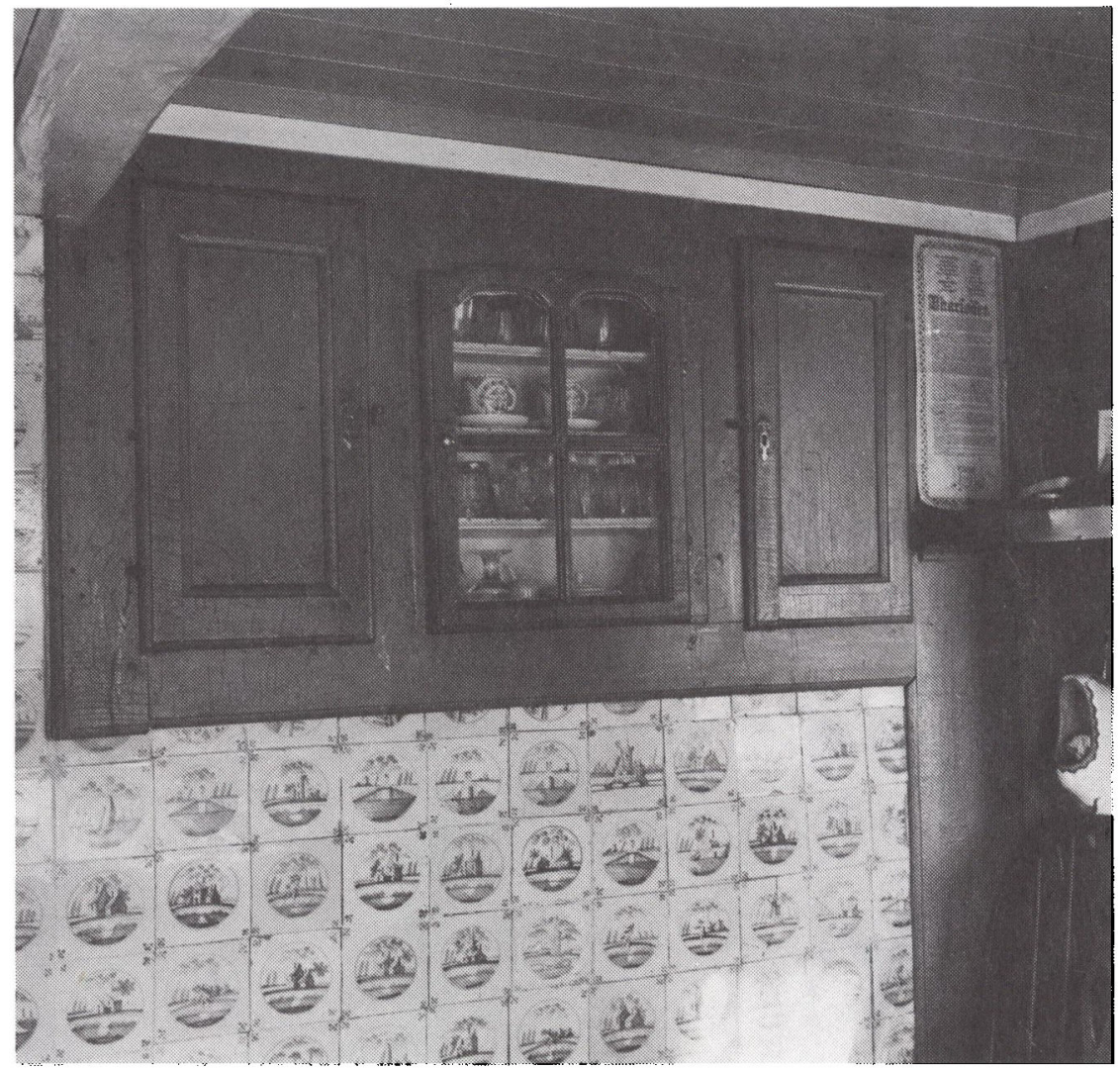

Skab på mandvaggen i sønderdørns i matr. nr. 126 Kirkeby.

\section{ORDLISTE}

Det åbne system er modsætningen til det lukkede, hvor hele bygværket er en sluttet type. Base, den nederste, profilerede, del af en pille eller søjle, der danner overgang mellem pillen og det, den hviler på.

Bjalkefagbredde, i bindingsværk afstanden fra midte til midte mellem nabobjælker.

Bjalkehoved $=$ bjælkeende.

Dokke, kort tømmerstykke, der i bindingsværk spænder mellem fodtømmer og løsholt og mellem løsholt og murrem. Der kan være 1 eller 2 dokker i hvert fag.

Fodtømmer, vandret tømmerstykke, der i bindingsværk hviler på fundamentet og bærer stolper og dokker.

Halvvalm, skrå gavltagflade, hvor tagskægget ligger højere end på langsiderne af huset. Jugendstil, tysk stilart fra ca. 1890-1900, frigjort fra de historiske stilarter og ofte påvirket af planteverdenens former. 
Kapital, den øverste, forsirede, del af en pille eller søjle, der danner overgang mellem pillen (søjlen) og den overliggende, bårne, konstruktion.

Kamning, udsparing i murremmens overside og bjælkens underside, hvorved bjælken forsænkes svagt i remmen på en sådan måde, at der sker en sammenlåsning.

Losholt, vandret tømmerstykke, som forbinder stolperne 2 og 2 , med sin overside i højde med vindueskarmens underside.

Murrem, vandret tømmerstykke, der i bindingsværk hviler på stolpernes øverste ende og danner underlag for bjælkerne.

Not, fordybet rille, f.eks. i gulvbrædder, der er pløjet sammen.

Pillefagbredde, i grundmur afstanden fra midte til midte mellem nabopiller.

Renassance, en stilretning, der i den sidste fjerdedel af 1800 -årene genoptog renæssancens arkitekturformer (= nyrenæssance).

Skelkalk, kalk der er brændt af muslingeskaller.

$S t i k$, muret overdækning over muråbninger. Ved lige og svagt buede stik står murstenene på enden med en svag hældning, så dets overside er bredere end dets underside. Hældningen aftager jævnt mod midten, hvor stenen står lodret.

Stødfuge, fuge mellem 2 brædder, der ligger i forlængelse af hinanden.

Vindskede, brædt, der ved gavle sømmes på muren og slutter mod stråtagets underside.

\section{NOTER}

Alle fotos og tegninger $\mathrm{i}$ artiklen er taget og udfort af forfatteren. Manuskriptet til artiklen, men med flere tegninger og farvefotos findes $\mathrm{i}$ Historiske Samlinger for Sønderjylland, Åbenrå.

1. Peter Michelsen: Bondehuses alder, side 42.

2. Matr. nr. 189 , Juvre, 53, Kongsmark og 34, Kirkeby.

3. R. Mejborg: Nordiske Bøndergaarde, s. 213.

4. Thade Petersen: Rømø, side 175, foto efter side 160 nederst.

5. Arkitekt Frode Kirk, Frilandsmuseet i Lyngby, har gjort opmærksom på, at der skal være naglehuller $\mathrm{i}$ bjælkernes overside efter fastgørelsen af dæksplankerne, for at det kan afgøres, at bjælkerne har været anvendt i et skib, og at bjælkekrumningerne kan være fremkommet ved, at ydervæggene, men ikke hovedskillerummet, har sat sig.

6. Matr. nr. 449, Kirkeby.

7. Matr. nr. 117, Kirkeby.

8. Matr. nr. 58, Kongsmark.

9. Matr. nr. 675, Kirkeby.

10. Oplyst af Peter Petersen, Havneby.

11. Matr. nr. 53, Kirkeby.

12. Matr. nr. 595, Kirkeby.

13. Matr. nr. 126 og 23 Kirkeby.

14. Meddelt af sognepræst Christian Jørgensen, Rømø.

15. Matr. nr. 13, Kongsmark.

16. Matr. nr. 74. Kirkeby. Den nu afdøde ejer, maskinmester Peter List, har fortalt, at han lavede stavene til sit stakit i sin fritid ombord. Han kunne få skadet træ gratis, fordi han sejlede med trælastskibe, og de korte stave kunne han føre toldfrit $i$ land.

17. Matr. nr. $58 \mathrm{~m}$. fl. Kongsmark.

18. Meddelt af lektor Betty Schmidt, København, og murerarbejdsmand Alfred Petersen, Rømø. 
